\title{
The co-evolution of Black Sea level and composition through the last deglaciation and its paleoclimatic significance
}

\author{
Candace O. Major ${ }^{\mathrm{a},{ }^{\star}}$, Steven L. Goldstein ${ }^{\mathrm{b}}$, William B.F. Ryan ${ }^{\mathrm{b}}$, Gilles Lericolais ${ }^{\mathrm{c}}$, Alexander M. \\ Piotrowski ${ }^{d}$ and Irka Hajdas ${ }^{\mathrm{e}}$
}

\author{
aDepartment of Geology and Geophysics, Woods Hole Oceanographic Institution, Woods Hole, MA \\ 02543, USA \\ ${ }^{b}$ Lamont-Doherty Earth Observatory and Department of Earth and Environmental Sciences, Columbia \\ University, Palisades, NY 10964, USA \\ 'IFREMER-Centre de Brest, DRO/GM-BP 70, F-29280 Plouzane cedex, France \\ ${ }^{\mathrm{d}}$ Department of Earth Sciences, University of Cambridge, Downing Street, Cambridge CB2 3EQ, UK \\ e Institut für Teilchenphysik (IPP), HPK H 27, ETH-Hoenggerberg, CH-8093 Zurich, Switzerland \\ *: Corresponding author : Tel.: +1 508289 2460; fax: +1 508289 2187; cmajor@whoi.edu
}

\begin{abstract}
:
The Black Sea was an inland lake during the last ice age and its sediments are an excellent potential source of information on Eurasian climate change, showing linkages between regionally and globally recognized millennial-scale climate events of the last deglaciation. Here, we detail changes from the last glacial maximum (LGM) through the transition to an anoxic marginal sea using isotopic (strontium and oxygen) and trace element $(\mathrm{Sr} / \mathrm{Ca}$ ) ratios in carbonate shells, which record changing input sources and hydrologic conditions in the basin and surrounding region. $\mathrm{Sr}$ isotope records show two prominent peaks between $\sim 18$ and $16 \mathrm{ka} \mathrm{BP}$ cal, reflecting anomalous sedimentation associated with meltwater from disintegrating Eurasian ice sheets that brought Black Sea level to its spill point. Following a sharp drop in Sr isotope ratios back toward glacial values, two stages of inorganic calcite precipitation accompanied increasing oxygen isotope ratios and steady $\mathrm{Sr}$ isotope ratios. These calcite peaks are separated by an interval in which the geochemical proxies trend back toward glacial values. The observed changes reflect negative water balance and lake level decline during relatively warm periods (Bølling-Allerød and Preboreal) and increasing river input/less evaporation, resulting in higher lake levels, during the intervening cold period (the Younger Dryas). A final shift to marine values in $\mathrm{Sr}$ and oxygen isotope ratios at $9.4 \mathrm{ka} \mathrm{BP}$ cal corresponds to connection with the global ocean, and marks the onset of sedimentation on the Black Sea continental shelf. This date for the marine incursion is earlier than previously suggested based on the appearance of euryhaline fauna and the onset of sapropel formation in the deep basin.
\end{abstract}




\title{
The co-evolution of Black Sea level and composition through the last deglaciation and its paleoclimatic significance
}

Candace O. Major ${ }^{1 *}$, Steven L. Goldstein ${ }^{1}$, William B. F. Ryan ${ }^{1}$, Gilles Lericolais ${ }^{2}$, Alexander M. Piotrowski ${ }^{1} \dagger, \&$ Irka Hajdas $^{3}$

${ }^{1}$ Lamont-Doherty Earth Observatory and Department of Earth and Environmental Sciences, Columbia University, Palisades, NY 10964, USA

${ }^{2}$ IFREMER - Centre de Brest, DRO/GM - BP 70, F-29280 Plouzane cedex, France

${ }^{3}$ Institut für Teilchenphysik (IPP), HPK H 27, ETH-Hoenggerberg, CH-8093 Zurich, Switzerland

*present address: Woods Hole Oceanographic Institution, Woods Hole MA 02543, USA

†present address: Dept. of Earth Sciences, University of Cambridge, Downing Street,

Cambridge, CB2 3EQ, UK

\begin{abstract}
The strontium and oxygen isotopic compositions of carbonate shells are a measure of the water delivered to the Black Sea lake since the last glacial maximum. Commencing at $\sim 18 \mathrm{ka} \mathrm{BP}$ cal with the arrival of substantial meltwater from the Alpine and northern European ice sheets and overflow via the Caspian Sea from the disintegrating Siberian ice cover, the ${ }^{87} \mathrm{Sr} /{ }^{86} \mathrm{Sr}$ ratio rose rapidly from a glacial minima around 0.7087 to reach a set of peaks near 0.7091 in layers of conspicuous reddish-brown clay with a mineralogy of Eurasian provenance. The ${ }^{87} \mathrm{Sr} /{ }^{86} \mathrm{Sr}$ ratio oscillates between high in the red-brown layers to low in interbedded gray clays with glacial era mineralogy, indicative that the meltwater came in pulses. On the other hand, the rise of the $\delta^{18} \mathrm{O}$ ratio from glacial low values of -7 per mil was delayed until15.2 ka BP cal, after the last meltwater pulse. The rising $\delta^{18} \mathrm{O}$ of the Black Sea lake corresponds with two episodes of calcite precipitation whose interruption corresponds to the Younger Dryas cold period. During each interval of calcite precipitation the $\delta^{18} \mathrm{O}$ increased a further 2 per mil, without variation in the ${ }^{87} \mathrm{Sr} /{ }^{86} \mathrm{Sr}$ composition. During cooling the ${ }^{87} \mathrm{Sr} /{ }^{86} \mathrm{Sr}$ ratio trended back toward its glacial value with little change in the $\delta^{18} \mathrm{O}$. The disparity between the $\mathrm{Sr}$ and $\mathrm{O}$ isotope behavior demonstrates that $\delta^{18} \mathrm{O}$ is not simply a signal of end-member mixing, but instead the $\delta^{18} \mathrm{O}$ record reflects changes in atmospheric moisture delivered to the Black Sea watershed. At $9.4 \mathrm{ka} \mathrm{BP}$ cal the ${ }^{87} \mathrm{Sr} /{ }^{86} \mathrm{Sr}$ composition shifted to that of the global ocean and remained there to the present. Since lake water is significantly depleted in strontium relative to seawater, any earlier leakage from the Mediterranean should have left a corresponding signal.
\end{abstract}

\section{Introduction}

The Black Sea is a large and deep body of water at the landward extreme of a string of marginal basins separated from each other by shallow sills. During glacial sea level low-stands the marine connection was severed and the Black Sea transformed into a giant lake (Arkhangel'skiy \& Strakov, 1938; Ross et al., 1970; Chepalyga, 1984; Mangerud et al., 2001) similar to the modern Caspian Sea. The evolving composition of the lake water reflected the hydrological, erosional, 
and geographical changes within its vast drainage area in Europe and Asia. Thus the Black Sea is well-situated to record climate changes in the continental interior. Prior studies have investigated the lithology and mineralogy of the glacial Black Sea lake sediments (Müller and Stoffers, 1974; Stoffers \& Müller, 1978; Shopov et al, 1986; Major et al., 2002), but have focused primarily on the lake-to-marine transition (Wall \& Dale, 1974; Deuser, 1972; Hay et al, 1991; Ryan et al., 1997; Lane-Serff et al., 1997).

Recent studies have begun to capitalize on the Black Sea's potential as a high-resolution climate archive (e.g. Ryan et al. 2003; Bahr et al, 2005). This study ties proxy records of provenance and hydrologic changes in the Black Sea to regional and hemispheric changes during the last deglaciation. We show that stable and radiogenic isotope ratios along with trace element chemistry of radiocarbon dated carbonate samples record the history of regional climate changes through this interval and the influx of marine water. The data point to a previously undocumented highstand of Black Sea level early in the deglaciation that was likely associated with outflow to the downstream Marmara and Mediterranean Seas, whose timing indicates a major linkage to the disintegration of large ice masses in the Eurasian continental interior (Grosswald, 1998; Denton et al., 1999; Grosswald and Hughes, 2002), as well as to ice rafting events in the North Atlantic and the associated decrease in strength of the meridional overturning circulation (McManus et al., 2004). We also show that the inundation by the Mediterranean began at $\sim 9.4 \mathrm{ka} \mathrm{BP}$ cal., earlier than previous indications of $\sim 7.6 \mathrm{ka} \mathrm{BP}$ cal. based on fauna and the onset of sapropel deposition in the Black Sea (Ryan et al. 1997).

\section{Geological Background}

The Black Sea is connected to the global ocean via the Bosporus and Dardanelles Straits, and receives runoff from over two million $\mathrm{km}^{2}$ of eastern Europe and western Asia (Fig. 1). The density contrast between Mediterranean water flowing into the Black Sea as an undercurrent and fresh continental runoff results in water column stratification, anoxic conditions in the deep water, and the deposition of laminated, organic-rich sediments below $200 \mathrm{~m}$ (Ross \& Degens, 1974; Calvert, 1990; Jones \& Gagnon, 1994; Arthur \& Dean, 1998). The modern water balance reflects an excess of input (precipitation + runoff + marine inflow) over evaporation (Shimkus $\&$ 
Trimonis, 1974; Ünlüata et al., 1990), which results in an outflow of intermediate salinity water (16 to 18\%o) to the basins downstream (Gunnerson \& Ozturgut, 1974).

Over the past 3 million years, as world sea level fluctuated relative to the sill depths with the growth and decay of large ice sheets, the Black Sea oscillated from a completely isolated interior lake to a marine environment more than eight times (Schrader, 1979; Zubakov, 1988). The most recent lacustrine stage, persisting during the last glacial period from before $25 \mathrm{ka} \mathrm{BP}$ until the early Holocene, is evidenced by low-chlorinity sediment pore fluids (Bruyevich, 1952; Manheim \& Chan, 1974), brackish to freshwater biotic assemblages (Nevesskaya, 1965; Wall \& Dale, 1974; Shcherbakov \& Babak, 1979; Aksu et al., 2002), and light oxygen isotope ratios $\left(\delta^{18} \mathrm{O}\right)$ in calcium carbonate (Deuser, 1972; Major et al., 2002). In fact, it has been estimated that the Black Sea has been lacustrine for $90 \%$ of its Pleistocene history (Ross, 1978), because the connection with the oceans across the shallow dividing sill requires peak interglacial sea levels. Drowned coastal and alluvial features and erosional unconformities on the continental shelves provide solid evidence of past Black Sea lake low-stands of up to -155 meters below present day sea level (mbsl) (Scherbakhov et al., 1978; Khrischev \& Georgiev, 1991; Ryan et al., 1997; Ballard et al., 2000; Aksu et al., 2002). These low stands indicate that the hydrologic balance of the "Black Sea lake" must have been negative in the past, analogous to the Caspian Sea. The relative freshness of the Black Sea prior to the most recent marine incursion requires that water from the prior marine connection (the Karangatian Stage, equivalent to Marine Isotope Stage 5e, the most recent full interglacial) was flushed out of the basin (Kvasov, 1968), necessitating periods of outflow (i.e., positive hydrologic balance) during the lacustrine stage.

The Holocene entrance of marine water into the Black Sea basin was accompanied by progressive introduction of salt-tolerant species whose calcium carbonate shells show secular changes in $\delta^{18} \mathrm{O}$ (Ryan et al., 1997; Aksu et al., 2002). Deep basin and continental slope cores document a pronounced shift in the $\delta^{18} \mathrm{O}$ of bulk carbonate from light freshwater values $(\sim-6$ per mil) to heavier values approaching the modern marine range $(0$ to $+2 \%$ ) between 9,000 and $8,000 \mathrm{y}{ }^{14} \mathrm{C}$ BP (10.1 to $8.85 \mathrm{ka} \mathrm{BP}$ cal.) (Deuser, 1972; Major et al., 2002). Over this interval the mollusk stratigraphy shows a change in assemblage reflecting a transformation to increasingly brackish environments (Popov, 1973; Shcherbakov \& Babak, 1979). Marine species of mollusks 
(Ryan et al, 1997) and dinoflagellates (Wall \& Dale, 1974) appear subsequently close to the onset of sapropel formation at 7,160 $\pm 50 \mathrm{y}{ }^{14} \mathrm{C}(\sim 7.6 \mathrm{ka} \mathrm{BP}$ cal. assuming a 400 year radiocarbon reservoir age for the modern Black Sea) (Jones \& Gagnon, 1994).

Ryan et al. (1997) suggested that the breach of the Bosporus Sill by rising glacioeustatic sea level occurred when Black Sea base level lay below the sill depth, based on sedimentologic and faunal evidence tied to shelf-wide unconformities in seismic reflection profiles. They concluded that reconnection resulted in a 'flooding' of the Black Sea with marine waters to bring its surface to the level of the global ocean. Aksu et al. (2002) challenged the 'flood' hypothesis, citing evidence of back-stepping barrier bars on the southern Black Sea shelf, whose age they infer by extrapolation to indicate a transgression already underway by $13 \mathrm{ka}$ BP cal. Görür et al (2001) report evidence of estuarine sediments nearly 20 m higher than the Bosporus Sill depth shortly before the proposed time of flooding, and conclude that the Black Sea lake must have been outflowing over its sill at the time of the marine reconnection, thus precluding a 'flood'. Freshwater outflow from the Black Sea was inferred from observations of sapropelic sediments and less salinity tolerant biotic assemblages in the "downstream" basins (Marmara, Aegean, and eastern Mediterranean Seas) shortly before the marine connection of the Black Sea (Aksu et al., 2002). However, these salinity inferences have been questioned by Sperling et al (2003), who show an increase in $\delta^{18} \mathrm{O}$ values in carbonates of the Marmara Sea during the proposed period of Black Sea outflow, i.e., the opposite sense of change to what would be expected from a major freshwater supply.

Knowing the level of the Black Sea at the time of the marine incursion is crucial in determining the mode of the marine input (i.e., gradual or catastrophic). Part of knowing this level involves understanding the mechanisms that controlled Black Sea level prior to the marine reconnection. This paper discusses the changes in the freshwater sources to the Black Sea during its isolation from the ocean, and shows linkages between regionally and globally recognized millennial scale climate events of the last deglaciation. We also show that the first marine input to the Black Sea occurred simultaneously with flooding of the Black Sea continental shelf, consistent with the hypothesis of Ryan et al (1997) but occurring more than a thousand years earlier than their proposed "flood" event. 


\section{Isotopic proxies for Black Sea hydrologic and source changes}

Changes in the oxygen isotopic compositions of natural waters can result from different processes, most importantly variability in mixing of waters with different compositions, and kinetic and biological fractionation. Deuser (1972) interpreted $\delta^{18} \mathrm{O}$ variations in Black Sea bulk carbonates in terms of mixing between isotopically heavy marine water and isotopically light freshwater, and showed that the isotopic change followed lithologic changes indicating density stratification (Fig. 2a). Other bulk carbonate $\delta^{18} \mathrm{O}$ records (Major et al., 2002) show a more complicated pattern prior to sapropel formation (Fig. 2b). Bulk carbonate $\delta^{18} \mathrm{O}$ records differ substantially from benthic shell $\delta^{18} \mathrm{O}$ (Fig. 2c), which begins to rise several thousand years prior to the bulk carbonate records. Clearly, interpretation of $\delta^{18} \mathrm{O}$ simply in terms of mixing will underestimate the influence of fractionation processes and source changes, which can be important in an isolated system such as the glacial Black Sea lake. The base-level changes inferred from drowned shorelines point to negative shifts in the hydrologic balance of the basin, indicating a relative increase in the influence of evaporation. Furthermore, shifts in meteoric water $\delta^{18} \mathrm{O}$, related to temperature oscillations, impart changes to the overall lake isotopic composition through runoff and precipitation (von Grafenstein et al., 1999). All of these factors result in a shift toward higher $\delta^{18} \mathrm{O}$ - the same sense of change expected from marine input. In order to distinguish between changes due to marine input and changes related to source and hydrologic changes we must employ a tracer that is insensitive to these latter effects.

In contrast to oxygen, strontium isotope ratios show no measurable fractionation from biological effects, or temperature or other environmental changes. Although the Sr isotope ratio of seawater has changed over geologic time, the value has remained constant over the several thousands of years studied in this paper (Henderson et al., 1994). Sr isotope ratios of continental water bodies, on the other hand, reflect the catchment geology and can differ substantially between drainage basins (e.g. Stein et al., 1997; Krom, 1999). Biological and inorganic precipitates record the changes, which result from input and mixing of different water sources, provided the endmembers are sufficiently different. Seawater (currently ${ }^{87} \mathrm{Sr} /{ }^{86} \mathrm{Sr}=0.709155$, Henderson et al., 1994) has not only a significantly different Sr isotope ratio from the average river water feeding 
the Black Sea $\left({ }^{87} \mathrm{Sr} /{ }^{86} \mathrm{Sr}=\sim 0.7088\right.$; Palmer $\&$ Edmond, 1989), but also a factor of $\sim 30$ higher concentration of dissolved Sr (Broecker \& Peng, 1982; Palmer \& Edmond, 1989). Therefore a small amount of seawater can impart a measurable signal. The salinity of modern Black Sea surface water, at $18 \%$, represents roughly a 1:1 mixture of marine and river water, and its predicted ${ }^{87} \mathrm{Sr} /{ }^{86} \mathrm{Sr}$ is $\sim 0.709142$, nearly that of seawater, reflecting the influence of the high proportion of marine-sourced Sr.

Early studies of Sr isotopes in Black Sea carbonates showed marine values in the uppermost coccolith-bearing sapropel and lower values (averaging 0.7073 \pm 0.0003 ) in the lower lacustrine sediment (Cox \& Faure, 1974). These measurements were on bulk carbonates rather than shells, and the differences were not interpreted directly in terms of changes in water chemistry. Rather they were interpreted as reflecting $\mathrm{Sr}$ in reworked Tertiary (low ${ }^{87} \mathrm{Sr} /{ }^{86} \mathrm{Sr}$ ) carbonates during the glacial lacustrine phase and in the marine Emiliani huxleyii coccolith during the Holocene. More recent studies in other marginal basins have relied on more precise measurements in carefully selected biogenic carbonates to detect changing marine influence and drainage reconfigurations in estuarine areas (Ingram \& Sloan, 1992; Israelson \& Buchardt, 1999). These studies reveal the sensitivity and robustness of the ${ }^{86} \mathrm{Sr} /{ }^{88} \mathrm{Sr}$ signal in such environments, and the great utility in combining records with other geochemical proxies, such as oxygen isotopes and trace element concentrations, that incorporate responses to important environmental variables like temperature and salinity. We show that the geochemical evolution in the Black Sea is associated with lithologic and faunal changes, and the timing of these changes is related to the climatic variations associated with the deglaciation.

\section{METHODS}

Materials used in this study were recovered during a joint French-Romanian BLASON mission in 1998 (cores from the Romanian margin) and a joint Russian-American expedition in 1993 (cores from the West Crimea margin and Kerch Strait areas) (Table 1). Radiocarbon ages for all Romanian margin cores (BLKS- and BLVK-) as well as a subset of the West Crimea and Kerch area cores were measured at the ETH-Hoenggerberg AMS facility, with the exception of a single sample (BLVK9814, $130 \mathrm{~cm}$ ) that was dated at both ETH and the CNRS AMS facility in Gif- 
sur-Yvette, France. The remaining West Crimea and Kerch area core dates were obtained from the NOSAMS facility at the Woods Hole Oceanographic Institution (see also Ryan et al., 1997). Mollusk shells were leached prior to measurement in order to decrease the effects of diagenetic carbon contamination. Nearly half of the samples analyzed for isotopes and trace elements come from dated horizons (Table 2); the remaining ages are assigned according to linear extrapolations between dated points. The dated shells themselves were not used for the other geochemical analyses.

$\delta^{18} \mathrm{O}$ was measured on a Micromass Optima $\mathrm{CO}_{2}$-source mass spectrometer at the LamontDoherty Earth Observatory with a Multiprep carbonate preparation device. Calibration to VPDB is via NBS-19 and an in-house standard. Reproducibility of the standards was $\pm 0.08 \%$ (1б). For Sr isotope analyses, mollusk shells were successively leached using a procedure modified from Bailey et al., (2000), first with $0.1 \mathrm{M} \mathrm{HCl}$ to remove diagenetic surface recrystallization, and then with $0.02 \mathrm{M} \mathrm{HCl}$ to partially dissolve the shell carbonate. Ostracod samples were cleaned with $5 \% \mathrm{H}_{2} \mathrm{O}_{2}$, and ten to fifteen individual valves (75 to $300 \mu \mathrm{g}$ total weight) were picked for analysis. Clay samples were isolated with the following procedure: 1) removal of calcium carbonate by agitation in a weak acetic acid solution, 2) removal of amorphous iron oxides by reaction with sodium citrate, sodium sulfate, sodium chloride and acetone, 3) removal of amorphous silica and aluminum oxides by reaction with sodium carbonate in an ultrasonic bath, and 4) separation of the $<2 \mu \mathrm{m}$ size fraction by settling. The clay fraction was then dissolved in

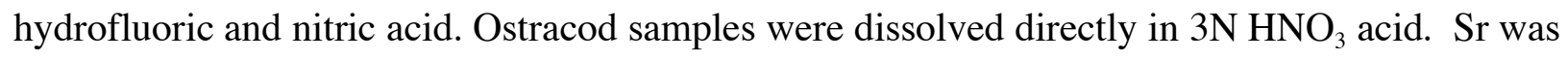
extracted using Eichrom Sr-spec resin. The Sr was loaded onto tungsten filaments with $\mathrm{TaCl}_{5}$ (Birck et al. 1986), and Sr isotope ratios were measured by dynamic multi-collection on a VG Sector 54 thermal ionization mass spectrometer at LDEO. ${ }^{87} \mathrm{Sr} /{ }^{86} \mathrm{Sr}$ ratios are normalized to ${ }^{86} \mathrm{Sr} /{ }^{88} \mathrm{Sr}=0.1194$. Beam size was maintained at close to $5 \times 10^{-11}$ amps for ${ }^{88} \mathrm{Sr}$. Instrument performance was monitored through analysis of NBS987, which gave ${ }^{87} \mathrm{Sr} /{ }^{86} \mathrm{Sr}=0.710288$ $( \pm 0.000015,2 \sigma$ external reproducibility, $\mathrm{n}=16)$. All ${ }^{87} \mathrm{Sr} /{ }^{86} \mathrm{Sr}$ ratios are further corrected to an NBS987 value of 0.710235 . Reported errors are the in-run $2 \sigma$ error of the mean. The ${ }^{87} \mathrm{Sr} /{ }^{86} \mathrm{Sr}$ of modern seawater carbonate was measured at $0.709150( \pm 0.000016,2 \sigma$ external reproducibility, $\mathrm{n}=6$ ), which is indistinguishable from that of the modern ocean (Henderson et al., 1994). Sample preparation and analyses for $\mathrm{Sr} / \mathrm{Ca}$ were carried out following the techniques described in Schrag 
(1999) and using characteristic spectral lines of $317 \mathrm{~nm}$ for calcium and $407 \mathrm{~nm}$ for strontium. Data were calibrated by comparison to the Mercenaria-3 standard. The average error (1 sigma) was for the standards $3.6 \%$, and replicate percent error was $1.6 \%$.

The changing environment in the Black Sea over the past 25,000 years and the broad depth range of our cores (-49 to $-378 \mathrm{~m}$ ) covering mid-shelf to upper slope environments meant that no single species could be used for the entire time period. While this is potentially significant for the $\delta^{18} \mathrm{O}$ (Wefer \& Berger, 1991) and $\mathrm{Sr} / \mathrm{Ca}$ (Rosenthal \& Katz, 1989), it is not a problem for ${ }^{87} \mathrm{Sr} /{ }^{86} \mathrm{Sr}$ (Faure, 1986). In the lacustrine sediments (prior to $\sim 9.4 \mathrm{ka} \mathrm{BP}$ cal) the $\delta^{18} \mathrm{O}$ data are . Though all $\mathrm{Sr} / \mathrm{Ca}(\mathrm{Ca} / \mathrm{Sr})$ data are presented in the data summary, we use only data from Dreissena species for identifying trends in the data. Some of the scatter in the $\delta^{18} \mathrm{O}$ younger than $\sim 9.2 \mathrm{ka} \mathrm{BP}$ cal. probably reflect interspecies offsets, but these differences are minor compared with the amplitude of the temporal changes within the Dreissena data.

In our discussion below, we assume that different proxies from a depth in a core represent the conditions at that point in time, however this assumption is not valid if a sedimentary unit includes a significant amount of reworked material. The lacustrine-marine boundary is commonly marked by a winnowed and reworked unit, referred to here as the 'shell hash'. Although each proxy data point from this unit is assigned an age based on the ${ }^{14} \mathrm{C}$ age of a shell from the same depth, due to the possibility of reworking the real age could be younger.

Therefore, we do not view data from the shell hash as representing a strict time series but rather a range of compositions within a discrete time window. Finally, the isotope and trace element records integrate data from three survey areas (Kerch Strait, West Crimea, and the Romanian margin). The coherency of the geochemical trends indicates that the major changes observed are basin scale, not local, although local phenomena may also account for some of the scatter in the data.

\section{RESULTS}

\section{Chronology}


Radiocarbon ages are converted to calendar ages (ka BP cal.) using the Calib 4.4 software (Stuiver et al., 1998; Stuiver and Reimer, 2004) assuming no reservoir correction (Major et al., 2002). The reservoir age (or the "hard water effect" resulting from the input of "dead" carbon to the basin by the weathering of carbonate rocks) for the lacustrine Black Sea is not known. Although other investigators (e.g. Jones \& Gagnon, 1994; Bahr et al., 2005) have assumed reservoir ages as large as 500 to 1000 years, we calculate calendar age using no reservoir correction and obtain good temporal relationships to regional calibrated climate records (Major et al., 2002). The observation that modern Black Sea reservoir age, at a time of persistent density stratification, is comparable to that of the North Atlantic (400 y) (Siani et al., 2000) suggests that the reservoir age of the Black Sea lake was probably have been smaller than the modern. Nonetheless it should be kept in mind that the real reservoir offset may be greater than zero and thus that the calibrated ages could be off by a hundred years or more. The age model presented here is acceptable for correlating millennial scale events such as the Bolling-Allerod warming or Younger Dryas cooling of the last deglaciation, both of which are of longer duration than feasible residence times. Age models for cores BLKS9809 and BLKS9810, as well as for other cores with multiple ${ }^{14} \mathrm{C}$ analyses, were constructed by linear interpolation between dated levels (Major et al., 2002).

\section{Isotope and trace element time series}

The main features of the isotopic records are described in several stages occurring over the past $\sim 25,000$ years (Fig. 3). These stages (labeled a through j) correspond closely with major lithologic units noted in sediment cores from the shelf and slope (Major et al., 2002; Ryan et al., 2003).

\section{$\sim 25$ to 18 ka BP cal. (stage j)}

In the earliest part of this Black Sea record, which includes the Last Glacial Maximum (LGM), both oxygen and strontium isotope ratios show low variability $\left({ }^{18} \mathrm{O}=-6.1\right.$ to $-7.2 \%,{ }^{87} \mathrm{Sr} r{ }^{86} \mathrm{Sr}=$ 0.70874 to 0.70882$)$ and $\mathrm{Sr} / \mathrm{Ca}$ ratios also shows fairly low variability ( $=2.4$ to $3.3, \mathrm{Ca} / \mathrm{Sr}=319$ to 418) (Fig. 3), although the resolution of the record is poor due to the scarcity of shell material. The ${ }^{87} \mathrm{Sr} /{ }^{86} \mathrm{Sr}$ values of shells older than $18 \mathrm{ka} \mathrm{BP}$ cal and associated with the LGM $(0.70874 \pm$ 
$0.000082 \sigma, N=13$ ) are close to a weighted average of the major rivers entering the Black Sea: the Danube, Dniepr, Don, and Sakarya rivers (0.70879; Table 3). Sr/Ca ratios in mollusk shells are offset from the average river input due to preferential incorporation of calcium relative to strontium (Turekian \& Armstrong, 1960); the partition coefficient for Dreissena in the Black Sea lake would be $\sim 0.6$, which is high relative to other aragonitic freshwater species (Rosenthal \& Katz, 1989). Other high-resolution proxy records (Major et al., 2002), such as clay mineralogy, carbonate content, and bulk carbonate stable isotopes, also suggest little variability in stage j. Sedimentation is mainly homogeneous grey mud.

\section{〜8 to 16 ka BP cal (stages g through i)}

Beginning at $\sim 18 \mathrm{ka} \mathrm{BP}$ cal, ${ }^{87} \mathrm{Sr} /{ }^{86} \mathrm{Sr}$ data show a marked rise from the earlier LGM values (stage i). The change in ${ }^{87} \mathrm{Sr} /{ }^{86} \mathrm{Sr}$ corresponds with the appearance of two reddish-brown clay layers, which have also been noted in other cores from the western Black Sea (Khrischev \& Georgiev, 1991; Bahr et al., 2005). These clays are characterized by a several-fold increase in illite and kaolinite (Major et al., 2002), which are the dominant clay types of the modern northern Black Sea shelf (Muller \& Stoffers, 1974), and much higher ${ }^{87} \mathrm{Sr} /{ }^{86} \mathrm{Sr}$ values (0.7509) than the grey clays above and below $(0.7235-0.7302)$ (Table 4). $\delta^{18} \mathrm{O}$ data show a slight but progressive decrease of $\sim 1 \%$ o to a minimum value of $-8.1 \%$ at $\sim 17.6 \mathrm{ka} \mathrm{BP}$ cal., and $\mathrm{Sr} / \mathrm{Ca}$ remains in the same range as in stage $\mathrm{j}$. After a brief return to grey mud similar to the LGM compositions and associated with falling ${ }^{87} \mathrm{Sr} /{ }^{86} \mathrm{Sr}$ (stage h), a second peak in ${ }^{87} \mathrm{Sr} /{ }^{86} \mathrm{Sr}$ occurs with the appearance of another thinner reddish-brown clay layer (stage g). $\mathrm{CaCO} 3$ reaches its lowest values within the reddish-brown clay layers $(<7 \%)$.

\section{$\sim 16$ to $15.2 \mathrm{ka} \mathrm{BP}$ cal (stage f)}

${ }^{87} \mathrm{Sr} /{ }^{86} \mathrm{Sr}$ values drop sharply above the red-brown clay zone, as does the "northern component" signature in the clay mineralogy (stage f). There is a doubling in carbonate content through the interval, reaching values higher than at any time previous in the record.

\section{2 to $9.4 \mathrm{ka}$ BP cal (stages c through e)}

Between 15.2 and $\sim 13.5 \mathrm{ka} \mathrm{BP}$ cal. (stage e, which includes the Bølling-Allerød warming), $\delta^{18} \mathrm{O}$ climbs progressively, reaching approximately $-4 \%$, and $\mathrm{Sr} / \mathrm{Ca}(\mathrm{Ca} / \mathrm{Sr})$ increases (decreases) to 
$\sim 4.5$ ( 220), while ${ }^{87} \mathrm{Sr} /{ }^{86} \mathrm{Sr}$ remains constant or decreases slightly. Sediments on the upper slope of the western Black Sea show much higher percentages of calcium carbonate (e.g. in core BLKS9810), peaking at over $40 \%$ between $\sim 14.7$ and $13.3 \mathrm{ka} \mathrm{BP}$ cal (Major et al., 2002). $\delta^{18} \mathrm{O}$ values between 13.5 and $12 \mathrm{ka} \mathrm{BP}$ cal (stage d, encompassing the Younger Dryas) are intermediate to those in the intervals before and afterward (stages e and c), although the data within this interval do not show a clear trend. ${ }^{87} \mathrm{Sr} /{ }^{86} \mathrm{Sr}$ ratios and $\mathrm{Sr} / \mathrm{Ca}(\mathrm{Ca} / \mathrm{Sr})$ show a slight decrease (increase) in stage $d$, carbonate contents significantly decrease, and silt-sand fractions significantly increase in continental slope settings (Major et al., 2002; Bahr et al., 2005). Between 11.6 and $9.4 \mathrm{ka} \mathrm{BP}$ cal (stage c, when temperatures in Greenland show a sustained increase toward full Holocene conditions), $\mathrm{CaCO}_{3}$ in the upper slope core (BLKS9810) shows a pronounced peak (to $>60 \%$ ), which is even higher than the Bølling-Allerød peak (stage e).

A single ${ }^{87} \mathrm{Sr} /{ }^{86} \mathrm{Sr}$ value of 0.709071 lies well off the trend defined by the other samples $(\sim 0.7089)$ in stage c. This outlier value reflects 5 measurements on 2 different shells of euryhaline species (Cardium and Adacna) from the same horizon at a present water depth of -55 m. The ${ }^{14} \mathrm{C}$ age of both shells, measured at two different labs, was $9,850 \pm 80(90){ }^{14} \mathrm{C}$ years $(\sim 10.85 \mathrm{ka} \mathrm{BP}$ cal.). The sedimentary unit from which this sample was taken is a greyish-brown silty clay with organic-rich laminae. This unit is bounded at the top and bottom by sharp erosional contacts, and is seen in seismic profiled to correspond to infill of a local depression in the shelf.

\section{4 to 0 ka BP cal (stages a and b)}

At $9.4 \mathrm{ka} \mathrm{BP}$ cal. (stage b, close to when Greenland temperatures reach full Holocene values), there is a sharp transition to lower $\mathrm{CaCO}_{3}$ and a pronounced increase in $\delta^{18} \mathrm{O},{ }^{87} \mathrm{Sr} /{ }^{86} \mathrm{Sr}$, and $\mathrm{Sr} / \mathrm{Ca}$. These changes signal the marine incursion, thus showing that marine input commences after the carbonate peak. Samples from the mixed cores indicate a slightly earlier timing for the marine input (9.5-9.2 ka BP cal). The difference reflects uncertainty in the BLKS9810 age model, in which the transition is dated by interpolation between a ${ }^{14} \mathrm{C}$ date of $10,640 \pm 80$ years at $94.5 \mathrm{~cm}$ and 7,100 years at $38.5 \mathrm{~cm}$, the base of the sapropel (Jones \& Gagnon, 1994) (see Table 1). The geochemical transition is associated with a change in lithology on the continental shelf and slope: a thin $(3 \mathrm{~cm})$, sharply defined grey-green mud lying between the grey carbonate-rich 
muds and the base of the sapropel in BLKS9810, and a unit of crushed and whole shells (shell hash) in the mixed-core samples. The shell hash unconformably overlies stiff, barren muds on the mid-shelf (from $<-92 \mathrm{~m}$ to at least $-50 \mathrm{~m}$ ) and Dreissena-bearing muds on the outer shelf, and is characterized by a more diverse and salinity-tolerant assemblage of mollusks (Ryan et al., 2003) and dinocysts (Mudie et al., 2004) than older lithologic units. The transitional period lasts until $~ 9.2 \mathrm{ka} \mathrm{BP}$ cal. After this time and until the present day, the $\delta^{18} \mathrm{O}$ and ${ }^{87} \mathrm{Sr} /{ }^{86} \mathrm{Sr}$ vary minimally, and are associated with the presence of Mediterranean-type mollusk species (e.g., Cardium and Mytilus).

\section{Interproxy relationships}

Each stage and its associated lithologic unit has a characteristic geochemical signature, and the evolution of water compositions can be illustrated through the relationships between proxies (e.g., ${ }^{87} \mathrm{Sr} /{ }^{86} \mathrm{Sr}$ vs $\delta^{18} \mathrm{O}$ in Fig. $4 \mathbf{a}$ and $4 \mathbf{c}$ and ${ }^{87} \mathrm{Sr} /{ }^{86} \mathrm{Sr}$ vs $\mathrm{Ca} / \mathrm{Sr}$ in Fig. 4b and 4d). Time periods corresponding to the glacial muds through the grey muds overlying the reddish-brown clays (stages $\mathrm{f}$ through $\mathrm{j}$ ) show variability in ${ }^{87} \mathrm{Sr} /{ }^{86} \mathrm{Sr}$ with no significant change in $\delta^{18} \mathrm{O}$ or $\mathrm{Ca} / \mathrm{Sr}$, whereas the carbonate-rich sediments and the intervening grey mud (stages c through e) show a progressive increase in $\delta^{18} \mathrm{O}$ without significant change in ${ }^{87} \mathrm{Sr} /{ }^{86} \mathrm{Sr}$. In contrast, ${ }^{87} \mathrm{Sr} /{ }^{86} \mathrm{Sr}, \delta^{18} \mathrm{O}$, and $\mathrm{Ca} / \mathrm{Sr}$ change together between the uppermost lacustrine sediments and the marine sediments (stages a through c).

\section{DISCUSSION}

\section{Evidence for marine incursion at $\sim 9.4 \mathrm{ka} \mathrm{BP}$ cal.}

The $\mathrm{Sr}$ isotope ratios of the biogenic carbonates, rising abruptly from 0.70891 to 0.70901 in stage b, clearly show the linkage between the Black Sea and the global ocean. The shell $\delta^{18} \mathrm{O}$ record also shows an offset in the same time period-- values prior to the transition are about $-2.6 \%$, and the amplitude of the $\delta^{18} \mathrm{O}$ shift is $\sim 2.1 \%$. Modern-day values are reached with the appearance of Mediterranean fauna at the beginning of stage 1, 9.2 ka BP cal, suggesting that exchange between the Black Sea and Mediterranean was similar to today by that time. Mixing relationships of both ${ }^{87} \mathrm{Sr} /{ }^{86} \mathrm{Sr}$ vs $\delta^{18} \mathrm{O}$ and ${ }^{87} \mathrm{Sr} /{ }^{86} \mathrm{Sr}$ vs $\mathrm{Ca} / \mathrm{Sr}$ both show a clear linear trend toward 
the marine endmember from the compositions characterizing the upper carbonate peak (CP-1). The 'shell hash' lies directly along this mixing line, indicating that the mollusks of this unit grew during the marine transition. Dinocyst assemblages in the corresponding transitional unit (B1c) from the deep southwestern basin also indicate increasing salinity and the presence of seawater Mudie et al., 2004). The timing of first marine input inferred from the Sr isotope and other geochemical data is earlier than the age of $\sim 7.5 \mathrm{ka} \mathrm{BP}$ cal. suggested by Ryan et al. (1997) on the basis of the first appearance of euryhaline marine fauna (e.g., Cardium edule). Thus the Black Sea contained marine water prior to the onset of sapropel deposition at $\sim 7.5 \mathrm{ka} \mathrm{BP}$ cal. This is consistent with models suggesting a time lag between the first marine inflow and the depletion of bottom water oxygen required for sapropel formation (Deuser, 1974; Lane-Serff et al., 1997). With the appearance of Mediterranean-type mollusk species such as Cardium exiguum and Mytilus galloprovincialis at $7.5 \mathrm{ka} \mathrm{BP}$ cal., dinoflagellates shifted to full euryhaline assemblages (Wall \& Dale, 1974; Atanassova, 1995), suggesting progressive salinification and a threshold control on the appearance of marine species.

While shell hash is found in cores recovered from a range of depths between -49 and -129 mbsl, those from cores shallower than -80 mbsl are never older than $9.4 \mathrm{ka} \mathrm{BP}$ cal. (Fig. 5). Below $100 \mathrm{mbsl}$ this unit contains older Dreissena shells, presumably reworked from the underlying coquina. Shallower than $-80 \mathrm{~m}$ the shell hash sits on an unconformable surface and organic carbon dates from the barren unit below are $>28 \mathrm{ka} \mathrm{BP}$ cal (Major, 2002). The lack of older intact shells at these shallower depths suggests that subaerial reworking, erosion, and abrasion produced the shell hash matrix that later served as a substrate for more salt tolerant species colonizing the Black Sea after the marine incursion. Such subaerial exposure is reflected in the low water contents of the shell hash and underlying sediments cored on the Black Sea shelf (Ryan et al., 1997). The timing of the first marine signal indicates that the Bosporus sill was breached when external (Mediterranean) sea level reached -30 m. Infill of the Sakarya River estuary at a depth of $-28 \mathrm{~m}$ began shortly after $9 \mathrm{ka} \mathrm{BP}$, characterized by the same mollusk assemblages as are found in the shell hash (Gorur et al., 2001), suggesting a more gradual rise of sea level following the reconnection. 
The simultaneous colonization of three areas of the Black Sea continental shelf by a diversified brackish water faunal assemblage at a large depth range suggests that: (1) the rise in Black Sea level across the shelf coincided with the marine incursion, and (2) the rise was abrupt enough to not result in onlapping sediments. These observations further suggest that the Black Sea was at a low stand at the time of the incursion, most likely corresponding to the drowned shoreline features at -70 to -90 m observed on both the Romanian and Russian margins (Ryan et al., 2003). The preservation of such features is further evidence for a rapid base level rise, since the bedforms were not destroyed by ravinement during the transgression. Other evidence for a powerful reworking event associated with the marine incursion includes a prominent peak in detrital input (Bahr et al., 2005) and grain size (Major et al., 2002) on the western continental shelf as well as a widespread "washout" surface between the Black Sea lake sediments and the base of the sapropel (Khrischev \& Georgiev, 1991).

Simple modeling of two scenarios for the incursion of marine water into a low Black Sea (a 'flood' with rapid filling versus gradual incursion at its spill point) show a good fit to the ${ }^{7} \mathrm{Sr} /{ }^{86} \mathrm{Sr}$ data (Fig. 6). The "flood" case assumes an abrupt input of marine water equal to the volume difference between a low-stand Black Sea $(-80 \mathrm{~m})$ and a Black Sea at its spill point $(-35 \mathrm{~m})$, accounting for a $4 \%$ volume increase, and shows a slightly better fit to the apparent early rise of ${ }^{87} \mathrm{Sr} /{ }^{86} \mathrm{Sr}$ ratios seen in the shell hash. However, because of the uncertainties in the dating and stratigraphic order as well as the presence of older reworked material within this unit, it is not possible to definitively distinguish between the two scenarios. It is clear, however, that the marine input caused a significant and geologically abrupt change in sedimentation as well as in the Black Sea water chemistry.

The shells dated at $9,850{ }^{14} \mathrm{C}$ y $(10.9 \mathrm{ka} \mathrm{BP}$ cal $)$ that lie well off the trend defined by stage $\mathrm{c}$ (Fig. 3) are from core BLVK9814, which lies at $-55 \mathrm{mbsl}$ in a shelf depression. The sample contains small specimens of the marine mollusks Cardium and Adacna not found in any of the time-equivalent lithologic units on the deeper shelf or slope. These shells have a $\delta^{18} \mathrm{O}$ value within the range of the other contemporaneous data, but ${ }^{87} \mathrm{Sr} /{ }^{86} \mathrm{Sr}$ close to modern seawater. We consider this to be coincidental, as a marine water influence at that shallow water depth would have left a recognizable imprint in the deeper parts of the basin. These shells also point to a 
different environment than in the open lake: the assemblage comprises only dwarfed specimens of Mediterranean-type species. Shcherbakhov \& Babak (1979) describe the same faunal assemblage in facies they interpret to be perched saline ponds along the Black Sea shelf and Sea of Azov, which were terrestrial settings during periods of lowered Black Sea level. The chemistry of such a small water body is sensitive to the local conditions, driven by evaporation, algal blooms, and groundwater leakage. The ${ }^{87} \mathrm{Sr} /{ }^{86} \mathrm{Sr}$ ratio is distinct from the Black Sea water at that time, which is significant because it implies that the level of the Black Sea lake lay below $55 \mathrm{mbsl}$ at $9,850{ }^{14} \mathrm{C}$ y (10.9 ka BP cal) and could not have been outflowing over a shallow sill.

\section{Implications of the pre-Bølling record (>15 ka BP cal)}

Following the low variability in all proxy records during the LGM (Fig. 3, stage j), a rapid increase in ${ }^{87} \mathrm{Sr} /{ }^{86} \mathrm{Sr}$ beginning at $\sim 18 \mathrm{y} \mathrm{BP}$ cal. (stage i) reaches near marine values by $17 \mathrm{ka} \mathrm{BP}$ cal. This increase cannot be due to early marine input because it occurred before the Mediterranean Sea reached the bedrock depth of the Dardanelles Sill ( -75 to $-80 \mathrm{~m}$, Yaltirak et al., 2002; Lambeck and Bard, 2000) and invaded the Marmara Sea, the first gateway to the Black Sea-Marmara corridor. Salinification of the Marmara Sea began much later, at 11,800 to 12,000 ${ }^{14} \mathrm{C}$ y ( $\sim 14 \mathrm{ka} \mathrm{BP}$ cal; Cagatay et al, 2000; Sperling et al, 2003). Furthermore, the decreases of ${ }^{87} \mathrm{Sr} /{ }^{86} \mathrm{Sr}$ in Black Sea shells in stages $\mathrm{h}$ and $\mathrm{f}$ would require a cut-off of marine input. Once a marine connection was established then, barring significant vertical motion at the sill, exchange cannot be shut off if global sea level continued to rise through the deglaciation (Fig. 5, c.f. Fairbanks, 1989; Siddall et al., 2003). These early variations in ${ }^{87} \mathrm{Sr} /{ }^{86} \mathrm{Sr}$, associated with changes in sedimentary input to the Black Sea, must therefore be due to changes in the freshwater sources. Rivers currently account for about one third of the total water input (Unluata et al., 1990) and less than $4 \%$ of the Sr input to the basin, but in a Black Sea lacking Mediterranean inflow the rivers would have contributed more than half the water balance (the remainder being from precipitation) and all of the strontium. Changes in relative fluxes of different rivers during the Black Sea lake phase, or in the Sr isotope ratios of individual rivers, would have had a measurable impact on the ${ }^{87} \mathrm{Sr} /{ }^{86} \mathrm{Sr}$ of the Black Sea lake. 
The short, two-peaked interval of high ${ }^{87} \mathrm{Sr} /{ }^{86} \mathrm{Sr}$ corresponding to the deposition of the reddishbrown clays (stages $\mathrm{g}$ and $\mathrm{i}$, prior to the Bølling warming) must record short-lived inputs from a more radiogenic source associated with anomalous runoff into the Black Sea. There is no present-day source of radiogenic Sr that can simply explain these shifts. However, the contemporaneous occurrence of high ${ }^{87} \mathrm{Sr} /{ }^{86} \mathrm{Sr}$ illite-rich reddish-brown clays suggests that the ${ }^{87} \mathrm{Sr} /{ }^{86} \mathrm{Sr}$ increase of Black Sea water was related to a change in the sediment load brought in by the northern rivers. Bahr et al (2005) note the same reddish-brown clays in their cores from the Romanian margin, and with their high-resolution data can identify four pulses of input (the oldest three of which are not individually distinguished in our isotopic data). An increase in the manganese content of the reddish-brown clays further points to decreased deep ventilation of the Black Sea lake during enhanced freshwater input. Greater erosion and river sediment loads during deglaciation are documented in Alpine flood plains (Hinderer, 2001), where they are linked to the abundance of unconsolidated sediment and scarce vegetation cover within the drainage basin as well as higher transport capacity of meltwater-bearing rivers. It is also possible that preferential release of ${ }^{87} \mathrm{Sr}$ during the early stages of weathering following deglaciation (c.f. Blum \& Erel, 1995) contributed to the high river water ${ }^{87} \mathrm{Sr} /{ }^{86} \mathrm{Sr}$ ratios.

It has been suggested that high water levels in the Caspian Sea, caused by meltwater delivered to the Volga and low evaporation rates resulting from cold temperatures, allowed spillover into the Black Sea via the Manych Depression (Chepalyga, 1984; Bahr et al., 2005). A 'chocolate clay' deposit in the Lower Volga valley marks the maximum transgression (early Khvalyn) of the Caspian Sea (Kroonenberg et al., 1997); the highstand (+50 m above modern sea level) has been tied to the most likely period of significant overflow into the Black Sea during the past 25,000 years (Menabde \& Svitoch, 1990). There is wide disagreement among dating methods on the ages of the early Khvalyn terraces, but the most reliable ${ }^{14} \mathrm{C}$ dating points to a maximum highstand soon after $15 \mathrm{ky}{ }^{14} \mathrm{C} \mathrm{BP}(\sim 18 \mathrm{ka}$ BP cal) (Svitoch, 1999; Kroonenberg et al., 1997). This timing is consistent with the appearance of the high ${ }^{87} \mathrm{Sr} /{ }^{86} \mathrm{Sr}$ reddish-brown clay in the western Black Sea, though whether the Caspian and Black Sea clays are the same remains to be determined by geochemical analyses. Overflow of water from the Caspian cannot alone explain the early ${ }^{87} \mathrm{Sr} /{ }^{86} \mathrm{Sr}$ rise in the Black Sea (unless the Caspian was significantly different than today), because the modern Caspian Sea water value (0.7082, Clauer et al., 2000) is too low. 
Whether the high ${ }^{87} \mathrm{Sr} /{ }^{86} \mathrm{Sr}$ clays on the western Black Sea margin are sourced from the Caspian or northwestern Black sea rivers, the explanation for the ${ }^{87} \mathrm{Sr} /{ }^{86} \mathrm{Sr}$ change must lie in a change in provenance of river sediment load (affecting the dissolved $\mathrm{Sr}$ ). Furthermore, the excess input (runoff + precipitation) over output (evaporation) of the region, reflected by high Caspian Sea levels and the overall increase input of northern source waters to the Black Sea, would have raised the level of the Black Sea, probably to its outflow. Such a base level rise is recorded on the Black Sea shelf by channel infilling commonly seen in seismic profiles (Ryan et al., 2003) and inferred from sediment cores (Skiba et al., 1975), though sediment from these channels are not yet reliably dated (Kaplin \& Selivanov, 2004).

The timing of the high ${ }^{87} \mathrm{Sr} /{ }^{86} \mathrm{Sr}$ pulses is consistent with changes in the European geomorphological systems and warmer climate $3 \mathrm{ky}$ prior prior to the Bølling warming. These include retreat of valley glaciers in the Alps (C. Schluchter, personal communication), and the incision of braided stream systems in the upper reaches of rivers feeding the Black Sea indicating marked increase in runoff (Kalicki \& Sanko, 1998; Huhmann et al., 2004). Moraines indicate that the leading edge of the Scandinavian ice sheet advanced into the watersheds of the Dniepr River during the last glacial period (Kalicki \& Sanko, 1998) and rerouted into the Black Sea and Caspian smaller rivers that had formerly drained north to the Baltic and Arctic Seas (Kvasov, 1968; Grosswald, 1980). The pulse of clay delivery to the Black Sea thus can be linked to a major melting phase of European ice (c.f. Denton et al. 1999). The $\sim 1 \%$ drop in $\delta^{18} \mathrm{O}$ within the reddish-brown clay layers marks the input of $\delta^{18} \mathrm{O}$ depleted melt waters to the Black Sea.

The meltwater event in the Black Sea occurs close in time to Heinrich Event 1 (H1), the last major ice rafting event of the last glacial period in the North Atlantic, and estimated at $\sim 17 \mathrm{ky}$ cal. (c.f. Hemming 2004). The strong double peak of the Black Sea ${ }^{86} \mathrm{Sr} /{ }^{88} \mathrm{Sr}$ record (Fig. 3) mirrors the double peak in ice-rafted detritus observed in high sedimentation rate records of $\mathrm{H} 1$ from the Nordic seas (Elliot et al., 2001). Although the uncertainty in our age model does not allow a precise determination of lead-lag relationships, several authors have argued for a lead of the European deglaciation relative to the North American deglaciation (e.g. Scourse et al., 2000), and have suggested that melting of the large Scandinavian ice sheets could have been the mechanism for the decrease in deep water formation that cooled the north Atlantic during H1 
(Knutz et al., 2002). The meltwater pulses seen in the Black Sea record indicate that the European ice sheet response to occurred in the continental area as well as the coastal marine areas. In addition, it suggests that the forcing that caused the disintegration of the ice was a widespread phenomenon and not simply a coastal area response to sea level rise (Grousset et al., 2000; Jones \& Keigwin, 1988).

Thus the Black Sea geochemistry and stratigraphy documents the pre-Bølling history of deglaciation in Europe, including two major melting events of the Fennoscandian ice sheet at 18.5-18.0 and $17 \mathrm{ky}$ cal BP. This early European warming is consistent with rapidly increasing Northern Hemisphere summer insolation beginning around 20 ka BP cal (Bard et al., 1990; Berger \& Loutre, 1991), and suggests a greater sensitivity of the smaller volume European ice sheets than the Laurentide ice sheet (Clark \& Mix, 2002) to orbital forcing.

\section{Climatologically-controlled changes after the Bølling warming}

Following the intense melting of the Fennoscandian ice sheet and alpine glaciers between 18 and $16 \mathrm{ka} \mathrm{BP}$ cal, the ice had retreated far enough that it was no longer a significant source of water to the Black Sea. No significant freshwater input to the Nordic seas occurs after the onset of the Bølling (Jones \& Keigwin, 1988; Koc \& Jansen, 1994; Lehman et al., 1991), with the possible exception of a light $\delta^{18} \mathrm{O}$ event associated with the drainage of the Baltic ice lake (Lehman \& Keigwin, 1992), which would not have affected drainage to the Black Sea. Meltwater thus cannot be called on as a mechanism to bring the Black Sea to its spill point later on, to deliver continuous downstream delivery of freshwater to Marmara and the Aegean throughout the deglacial and post-glacial phases, as some authors have suggested (Stanley \& Blanpied, 1980; Lane-Serff et al., 1997; Aksu et al., 1999, 2002; Hiscott et al, 2002).

The increase in $\delta^{18} \mathrm{O}$ of mollusk shells following the Bølling warming (Fig. 3, stage e) occurs along with the appearance of inorganic carbonate in core BLKS9810 from the western shelf. The low ${ }^{87} \mathrm{Sr} /{ }^{86} \mathrm{Sr}$ at this time rules out the possibility of marine inflow being responsible for the increase in the $\delta^{18} \mathrm{O}$. The inorganic carbonate peaks record a much lighter $\delta^{18} \mathrm{O}$ signature (-6.5 to $-8.9 \%$ ) (Major et al., 2002) than do mollusks (-4.3 to $-2.5 \%$ ) of the same age. Carbonate 
precipitation is common in temperate lakes, where it commonly results from seasonal or permanent supersaturation of surface waters. It is often related to biological activity (Kelts \& Hsu, 1978), or "chemical delta" formation in the vicinity of bicarbonate-rich river outflows, such as the Danube (Shimkus \& Trimonis, 1974), mixing with lake waters (Hardie et al., 1978). The relatively light $\delta^{18} \mathrm{O}$ of the carbonate peaks suggests precipitation in warmer and/or fresher surface water. Several factors could account for the progressive shift in the mollusk $\delta^{18} \mathrm{O}$ record, including (i) a change in the meteoric water composition linked to northerly migration of the climate zones (Rozanski et al., 1992; von Grafenstein et al., 1999), (ii) a change in the hydrologic balance of the basin, namely an increase in evaporation relative to precipitation (Buchardt \& Fritz, 1980), or (iii) some combination of these processes. In the case of a change in the meteoric water composition, we would expect a gradual change in the $\delta^{18} \mathrm{O}$ of the Black Sea, reflecting the relatively small influx rate compared to the large reservoir volume. In this context, Central European lakes show a $4 \%$ o shift toward heavier $\delta^{18} \mathrm{O}$ at the time of the Bølling warming (von Grafenstein et al., 1999), which is consistent with the progressive change from -7\%o to $3 \%$ o between 15 and $9.4 \mathrm{ka} \mathrm{BP}$ cal in the Black Sea. This suggests that much of the $\delta^{18} \mathrm{O}$ shift in Black Sea biogenic carbonates may be explained by changes in meteoric water oxygen isotope compositions, thought evaporative processes could also play a role in changing the $\delta^{18} \mathrm{O}$ of the basin (Major et al., 2002; Bahr et al., 2005).

Nevertheless there is abundant evidence that the water balance of the Black Sea basin must have reversed following the meltwater-driven high-stand. The presence of preserved shoreline deposits on the Black Sea outer shelf and shelf-wide and upper slope unconformities post-dating the meltwater pulse (Ryan et al, 2003) indicates a late stage low-stand, and gypsum-rich sediments in the Marmara Sea (Stanley \& Blanpied, 1980), indicate evaporative conditions in that basin. There is an absence of any continuous sedimentary record of a late-glacial to early Holocene high-stand in any of the three survey areas of the northern and western continental Black Sea shelves. Bahr et al. (2005) note a large (at least four-fold) upslope increase in sedimentation rates in the lacustrine units above the reddish-brown clay layers which they ascribe to a more proximal location of their core sites on the continental slope to the Danube Delta during times of lowered Black Sea level. Conversely, the older red clay layers do not show such a dramatic increase in thickness with decreasing depth, even though terrigenous input 
is very high (Bahr et al., 2005), which is consistent with a more hemipelagic sedimentation on the continental slope during high Black Sea lake level. Finally, the change in $87 \mathrm{Sr} / 86 \mathrm{Sr}$ during the deposition of the carbonate peaks is minimal compared to the isotopic changes associated with the reddish-brown clays. Either decreased runoff (substantial enough to prevent significant changes to the isotopic composition of the Black Sea reservoir) or a change in the average river source to an intermediate value of between 0.7088 and 0.7089 could explain the minimal $87 \mathrm{Sr} / 86 \mathrm{Sr}$ shift, however the $87 \mathrm{Sr} / 86 \mathrm{Sr}$ of the clays suggest that if anything the post-reddishbrown clay run-off was less radiogenic than at the LGM. In all, the observations are best explained by a high Black Sea lake level fed by anomalous runoff during the meltwater event(s), followed by a decreasing Black Sea lake level with reduced freshwater input in the warmer climatic period of the Bolling/Allerod.

In contrast to stages $\mathrm{c}$ and e, respectively the warm periods of the Preboreal and Bolling-Allerod, the cool Younger Dryas period (stage d) shows a marked decrease in $87 \mathrm{Sr} / 86 \mathrm{Sr}$ and $\mathrm{Sr} / \mathrm{Ca}$ back toward compositions typical of the LGM (Fig. 4d). The Younger Dryas-aged sediments are most closely associated with the Dreissena-rich muds ("coquinas") of the typical "Neoeuxine" deposits of the Black Sea . Shcherbakhov et al. (1978) map the extent of a transgression of such Neoeuxine deposits up to the $-30 \mathrm{~m}$ isobath, though shallower than $-80 \mathrm{~m}$ it is identified only as a winnowed shell gravel. Although pollen assemblages throughout Europe identify the Younger Dryas as the driest period of the last glacial cycle (Rossignol-Strick, 1995), nonetheless it appears that the Black Sea level may have been rising through this time interval, perhaps as high as its outflow at $-30 \mathrm{~m}$. A late Pleistocene highstand of the Caspian (Late Khvalyn, Kroonenberg et al., 1997), the last major transgression before the drop to low Holocene water levels, reflects a positive regional water balance associated with the latest glacial period. Freshening of the Caspian and Black Seas during the Younger Dryas is also indicated by the presence of the diatom Stephanodiscus astrea (Shimkus et al., 1973). Higher Black Sea lake levels during the Younger Dryas may then be related to greatly reduced evaporation rates because of cold temperatures and ice cover, even though precipitation and runoff may have also been reduced. However, the rapid and early salinification of the much smaller downstream Sea of Marmara, observed in the very heavy $\delta^{18} \mathrm{O}$ composition of marine planktonic foraminifera starting at $12 \mathrm{ka}$ 
BP cal (Sperling et al., 2003), indicates an absence of continuous Black Sea flow during the Younger Dryas.

The late glacial sequences across the Black Sea continental shelf and slope are truncated by an erosional surface (Khrischev \& Georgiev, 1991; Major et al., 2002; Ryan et al., 2003). The sediment overlying the erosional surface has a euryhaline faunal assemblage at shallower depths or sapropelic sediments at depths greater than $\sim-200 \mathrm{~m}$. The presence of highly CaCO3-rich sediments in Preboreal time (stage c) suggests an environment comparable to that of the BollingAllerod warming, that is, increased evaporation and a lowering of Black Sea level in the period just prior to the marine incursion.

\section{CONCLUSIONS}

Geochemical data show that the marine influence on Black Sea water chemistry began $~ 9,400 \mathrm{y}$ BP cal and triggered changes in mollusk assemblages and the first faunal colonization atop a shelf-wide unconformity. The concurrence of the abrupt increases in ${ }^{87} \mathrm{Sr} /{ }^{86} \mathrm{Sr}$ and $\delta^{18} \mathrm{O}$ to marine compositions in mollusks sampled from a thin shell gravel horizon atop the unconformity suggests that the incursion of Mediterranean water may have been the causative agent for the drowning of the lake margin. The date of $7.5 \mathrm{ka} \mathrm{BP}$ cal reported by Ryan et al. (1997) is not the incursion itself, but time when salinity rose to a sufficient threshold for a introduction of euryhaline taxa following the first brackish species.

Variability of strontium and oxygen isotopes in Black Sea biogenic carbonates since 25 and prior to $9.4 \mathrm{ka} \mathrm{BP}$ are the result of changes in freshwater sources and do not reflect any marine influence. By $15 \mathrm{ka} \mathrm{BP}$ cal, the retreat of the Eurasian ice sheets and Alpine glaciers removed meltwater sources from the Black Sea drainage. The Sr and O- isotope data from Black Sea sediments and shells are consistent with sedimentological and morphological evidence of a lowstand, which would rule out continuous downstream delivery of freshwater to Marmara and the Aegean, and consistent with rapid and early salinification of the Sea of Marmara at $12 \mathrm{ka} \mathrm{BP}$ cal (Sperling et al., 2003). 
These source changes are correlated to major climate episodes recognized throughout the northern hemisphere, such as the deglaciation of northern Europe and the Alps, Heinrich Event H1, the Bølling-Allerød warmings and Younger Dryas cold episode. The input of freshwater into the north Atlantic from the retreat of European ice may be the link between the timing of the meltwater pulse into the Black Sea and Heinrich Event H1.

If the association of calcite precipitation before and after the Younger Dryas along with increasing $\delta^{18} \mathrm{O}$ and a correlation in time with lowstand shorelines around the Black Sea's lake is indicative of excess evaporation over supply, then the Black Sea behaved similarly to the Caspian in response to regional climate warming (i.e., expanded when cool, shrunk when warm). Highstands in warm periods may then be limited to special times of either rapid melting of ice sheets or times of marine connection as global sea level reached its maximum elevation.

\section{ACKNOWLEDGEMENTS}

The cores were collected aboard the French Le Suroit as part of the BLASON program with the collaboration of IFREMER and GEOECOMAR in Bucharest, and aboard the $R / V$ Aquanaut of the Southern Branch of the P. P. Shirshov Insitute of Oceanology. We thank Namik Çagatay, François Guichard, Wallace Broecker, Taro Takahashi, Walter Pitman, Peter DeMenocal, Jean Lynch-Stieglitz, Richard Fairbanks, Kazimeras Shimkus (now deceased), and Nicolae Panin for helpful discussions. Supported by grant OCE 97-11320 of the US National Science Foundation and a Grant in aid of research from Sigma Xi (to Major).

Correspondence and requests for materials should be addressed to Candace O. Major. (e-mail: cmajor@whoi.edu).

\section{TABLES}

Table 1: Core locations

\begin{tabular}{llcccc} 
Core name & Survey area & $\begin{array}{c}\text { Water depth } \\
(\mathbf{m})\end{array}$ & $\begin{array}{c}\text { Core length } \\
(\mathbf{c m})\end{array}$ & $\begin{array}{c}\text { Latitude } \\
(\mathbf{E})\end{array}$ & $\begin{array}{c}\text { Longitude } \\
(\mathbf{N})\end{array}$ \\
\hline BLVK9801 & Danube (Blason) & 92 & 49 & $44^{\circ} 15.2^{\prime}$, & $30^{\circ} 24.68^{\prime}$ \\
BLKS9803 & Danube (Blason) & 93 & 266.5 & $44^{\circ} 14.6^{\prime}$ & $30^{\circ} 26.11^{\prime}$ \\
BLKS9804 & Danube (Blason) & 101 & 81 & $44^{\circ} 12.0^{\prime}$ & $30^{\circ} 32.21^{\prime}$ \\
BLKS9805 & Danube (Blason) & 131 & 102 & $44^{\circ} 8.95^{\prime}$, & $30^{\circ} 39.24^{\prime}$ \\
BLKS9806 & Danube (Blason) & 135 & 265 & $44^{\circ} 7.38^{\prime}$, & $30^{\circ} 42.98^{\prime}$ \\
BLKS9807 & Danube (Blason) & 163 & 324 & $44^{\circ} 5.76^{\prime}$ & $30^{\circ} 46.80^{\prime}$ \\
BLKS9808 & Danube (Blason) & 186 & 368 & $44^{\circ} 5.47^{\prime}$, & $30^{\circ} 47.21^{\prime}$
\end{tabular}




\begin{tabular}{|c|c|c|c|c|c|}
\hline BLKS9809 & Danube (Blason) & 240 & 844 & $44^{\circ} 5.23^{\prime}$ & $30^{\circ} 47.98^{\prime}$ \\
\hline BLKS9810 & Danube (Blason) & 378 & 759 & $44^{\circ} 4.04^{\prime}$ & $30^{\circ} 50.68^{\prime}$ \\
\hline BLVK9814 & Danube (Blason) & 55 & 32 & $44^{\circ} 7.99^{\prime}$ & $29^{\circ} 19.53^{\prime}$ \\
\hline BLVK9815 & Danube (Blason) & 55 & 119 & $44^{\circ} 8.13^{\prime}$ & $29^{\circ} 21.85^{\prime}$ \\
\hline BLKS9830 & Danube (Blason) & 70 & 187.5 & $44^{\circ} 0.64^{\prime}$ & $29^{\circ} 53.72^{\prime}$ \\
\hline BLKS9831 & Danube (Blason) & 75 & 188 & $44^{\circ} 1.9^{\prime}$ & $29^{\circ} 54.84^{\prime}$ \\
\hline BLKS9832 & Danube (Blason) & 75 & 140 & $44^{\circ} 1.56^{\prime}$ & $29^{\circ} 56.29^{\prime}$ \\
\hline BLKS9834 & Danube (Blason) & 76 & 253.5 & $44^{\circ} 0.66^{\prime}$ & $29^{\circ} 53.71^{\prime}$ \\
\hline BLKS9837 & Danube (Blason) & 68 & 92 & $44^{\circ} 0.54^{\prime}$ & $29^{\circ} 58.87^{\prime}$ \\
\hline BLKS9838 & Danube (Blason) & 77 & 194 & $44^{\circ} 2.86^{\prime}$ & $29^{\circ} 56.79^{\prime}$ \\
\hline BS1 & Dneipr & 68 & 134 & $44^{\circ} 57.6^{\prime}$ & $32^{\circ} 5.5^{\prime}$ \\
\hline BS2 & Dneipr & 59 & 38 & $45^{\circ} 3.7^{\prime}$ & $32^{\circ} 1.6^{\prime}$ \\
\hline BS3 & Dneipr & 49 & 58 & $45^{\circ} 21.9^{\prime}$ & $31^{\circ} 49.7^{\prime}$ \\
\hline $\mathrm{BS} 4$ & Dneipr & 47 & 57 & $45^{\circ} 30.1^{\prime}$ & $31^{\circ} 43.0^{\prime}$ \\
\hline BS5 & Dneipr & 44 & 53 & $45^{\circ} 33.8^{\prime}$ & $31^{\circ} 40.5^{\prime}$ \\
\hline BS6 & Dneipr & 79 & 187 & $44^{\circ} 56.0^{\prime}$ & $32^{\circ} 7.3^{\prime}$ \\
\hline BS7 & Dneipr & 108 & 145 & $44^{\circ} 53.4^{\prime}$ & $32^{\circ} 9.3^{\prime}$ \\
\hline BS8 & Dneipr & 99 & 159 & $44^{\circ} 54.4^{\prime}$ & $32^{\circ} 8.5^{\prime}$ \\
\hline BS9 & Dneipr & 123 & 170 & $44^{\circ} 53.0^{\prime}$ & $32^{\circ} 9.2^{\prime}$ \\
\hline BS10 & Dneipr & 106 & 175 & $44^{\circ} 53.5^{\prime}$ & $32^{\circ} 8.8^{\prime}$ \\
\hline BS11 & Dneipr & 91 & 197 & $44^{\circ} 55.2^{\prime}$ & $32^{\circ} 8.0^{\prime}$ \\
\hline BS12 & Dneipr & 78 & 146 & $44^{\circ} 58.8^{\prime}$ & $32^{\circ} 11.1^{\prime}$ \\
\hline BS13 & Dneipr & 165 & 190 & $44^{\circ} 55.3^{\prime}$ & $32^{\circ} 16.5^{\prime}$ \\
\hline BS14 & Dneipr & 140 & 305 & $44^{\circ} 51.6^{\prime}$ & $32^{\circ} 21.3^{\prime}$ \\
\hline BS19 & Kerch & 63 & 142 & $44^{\circ} 43.2^{\prime}$ & $36^{\circ} 31.3^{\prime}$ \\
\hline BS20 & Kerch & 73 & 312 & $44^{\circ} 42.6^{\prime}$ & $36^{\circ} 33.5^{\prime}$ \\
\hline BS21 & Kerch & 90 & 347 & $44^{\circ} 41.4^{\prime}$ & $36^{\circ} 33.8^{\prime}$ \\
\hline BS22 & Kerch & 129 & 118 & $44^{\circ} 39.2^{\prime}$ & $36^{\circ} 35.2^{\prime}$ \\
\hline BS23 & Kerch & 150 & 278 & $44^{\circ} 40.2^{\prime}$ & $36^{\circ} 32.7^{\prime}$ \\
\hline BS24 & Kerch & 110 & 347 & $44^{\circ} 40.0^{\prime}$ & $36^{\circ} 34.5^{\prime}$ \\
\hline
\end{tabular}

Table 2: Data summary (see attached excel file)

Table 3: Sr inputs to the Black Sea

$\begin{array}{cccccc}\begin{array}{c}\text { modern flow } \\ \text { \% of total river } \\ \text { input }\end{array} & { }^{87} \mathbf{S r} /{ }^{86} \mathbf{S r} & {[\mathbf{S r}]} & {[\mathbf{C a}]} & \begin{array}{c}\mathbf{S r} / \mathbf{C a} \\ (\mathbf{C a} / \mathbf{S r})\end{array} & \text { data source } \\ \begin{array}{c}\text { from Shimkus \& } \\ \text { Trimonis, 1974) }\end{array} & & \mathrm{ppm} & \mathrm{ppm} & \begin{array}{c}\mathrm{mg} / \mathrm{g} \\ (\mathrm{g} / \mathrm{mg})\end{array} & \\ 53 & 0.7089 & 0.24 & 49 & \begin{array}{c}4.9 \\ (203)\end{array} & \begin{array}{l}\text { Palmer \& Edmonds, } \\ 1989 ; \text { Shimkus \& } \\ \text { Trimonis, } 1974\end{array} \\ 14 & 0.7085 & 0.22 & 45 & \begin{array}{c}4.9 \\ (205)\end{array} & \begin{array}{l}\text { Palmer \& Edmonds, } \\ 1989 ; \text { Shimkus \& }\end{array}\end{array}$




\begin{tabular}{|c|c|c|c|c|c|c|}
\hline Don & 7 & 0.7085 & 0.22 & 53 & $\begin{array}{c}4.2 \\
(241)\end{array}$ & $\begin{array}{l}\text { Trimonis, } 1974 \\
\text { Palmer \& Edmonds, } \\
\text { 1989; Shimkus \& } \\
\text { Trimonis, } 1974\end{array}$ \\
\hline Sakarya & $\sim 4$ & 0.7089 & & & & This study \\
\hline River average & & 0.708792 & 0.24 & 48.6 & $\begin{array}{c}4.8 \\
(207)\end{array}$ & \\
\hline $\begin{array}{l}\text { Seawater } \\
\text { (global average) }\end{array}$ & & 0.709155 & 7.62 & 413 & $\begin{array}{l}18.5 \\
(54)\end{array}$ & $\begin{array}{l}\text { Henderson et al., 1994; } \\
\text { Broecker and Peng, } 1982\end{array}$ \\
\hline $\begin{array}{l}\text { Aegean Sea } \\
\text { (modern) }\end{array}$ & & 0.709157 & & & & This study \\
\hline $\begin{array}{l}\text { Marmara Sea } \\
\text { (modern) }\end{array}$ & & 0.709150 & & & & This study \\
\hline
\end{tabular}

Table 3: Clay fraction $87 \mathrm{Sr} / 86 \mathrm{Sr}$

\begin{tabular}{ccccc} 
Core & $\begin{array}{c}\text { Depth in core } \\
(\mathbf{c m})\end{array}$ & $\begin{array}{c}\text { Age } \\
(\mathbf{y ~ B P ~ c a l .})\end{array}$ & Stage & ${ }^{87} \mathbf{S r}{ }^{86} \mathbf{S r}$ \\
\hline BLKS9810 & 68.5 & 10,790 & $\mathbf{c}$ & 0.723503 \\
BLKS9810 & 98.5 & 12,810 & $\mathbf{d}$ & 0.727401 \\
BLKS9810 & 330 & 17,980 & $\mathbf{i}$ & 0.750934 \\
BLKS9810 & 460 & 19,070 & $\mathbf{j}$ & 0.730184
\end{tabular}

\section{FIGURE CAPTIONS}

Figure 1: Map of the Black Sea and surrounding region, with rivers of present-day drainage area. Core locations from the Romanian margin (A), West Crimea (B), and Kerch Strait (C) survey areas are indicated.

Figure 2: Comparison of oxygen isotope records from the Black Sea: (A) $\delta^{18} \mathrm{O}_{\text {bulk carbonate }}$ from core $1474 \mathrm{~K}(2,117 \mathrm{~m})$ (Deuser, 1972), (B) $\delta^{18} \mathrm{O}_{\text {bulk carbonate }}$ from core BLKS9810 (378 m), and (C) $\delta^{18} \mathrm{O}_{\text {shell }}$ measured on mollusk shells in various cores from the three survey areas. Note that (A) and $(\mathrm{B})$ are plotted vs depth in core (cm), while (C) is plotted vs age (ka BP cal.). Radiocarbon dated levels are indicated for (A) and (B). Correlations between records are indicated with dashed lines; grey shaded bars indicate depth $(a, b)$ or age $(c)$ of marine incursion.

Figure 3: (A) GISP $2 \delta^{18} \mathrm{O}_{\text {ice }}$ (Grootes et al., 1993), (B) \% carbonate from core BLKS9810 (from

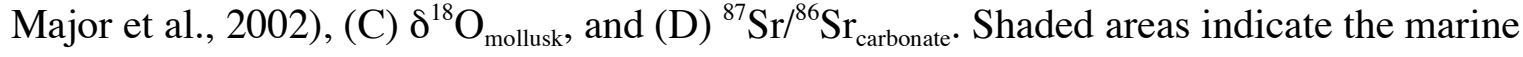
section (green), carbonate peaks (blue), and reddish-brown clay layers (pink). Data symbols for the $\delta^{18} \mathrm{O}_{\text {mollusk }}$ and ${ }^{87} \mathrm{Sr} /{ }^{86} \mathrm{Sr}_{\text {carbonate }}$ denote the lithologic unit from which the samples were taken (light green: shelly shelf muds with euryhaline mollusks, dark green: shelly shelf muds with mixed marine/brackish fauna, white: shell hash, blue: carbonate-rich muds, brown: shelf channel 
fill, grey: grey mud, brown: reddish-brown muds); a through j denote unit labels used in Figure 4. Data are included in Table 2.

Figure 4: ${ }^{87} \mathrm{Sr} /{ }^{86} \mathrm{Sr}$ vs $\delta^{18} \mathrm{O}$ data cross plot (A) and schematic (B), and ${ }^{87} \mathrm{Sr} /{ }^{86} \mathrm{Sr}$ vs Ca/ $\mathrm{Sr}$ data cross plot (C) and schematic (D). $\mathrm{Ca} / \mathrm{Sr}$ is used to highlight the linear mixing relationship between end members. (a) through (j) refer to time slices of the geochemical data corresponding to the major lithologic changes in the shelf and slope cores (see Fig. 3). Colored symbols in (A) and (B) represent average values within each stage, and error bars (and colored shading) representing $2 \sigma$ standard deviation.

Figure 5: Model comparison with data for a gradual inflow scenario (grey solid line) and a flood or "dam break" scenario (black dashed line). Data symbols are the same as in Fig. 3.

Figure 6: Sample age vs core depth. Symbols correspond to lithologic unit and/or mollusk assemblage (green circle: euryhaline (marine) fauna, white triangles: brackish fauna in shell hash, grey circles -Dreissena, brown square: euryhaline fauna in channel fill, red star: peat deposit (Gorur et al., 1998)). Thin dashed line is ice-equivalent sea-level (Fleming et al., 1998). The marine linkage at at $9.4 \mathrm{ka} \mathrm{BP}$ cal. indicates a sill depth of $\sim 30 \mathrm{~m}$. Grey bar indicates the depth range of well-preserved coastal bedforms, which lie well below the depth of contemporaneous glacio-eustatic sea level from $14 \mathrm{ka} \mathrm{BP}$ cal (Ryan et al., 2003). The channel fill sample is several tens of meters shallower than immediately older and younger samples.

\section{REFERENCES}

Aksu, A.E. et al., 2002. Last glacial-Holocene paleoceanography of the Black Sea and Marmara Sea: stable isotopic, foraminiferal and coccolith evidence. Marine Geology.

Aksu, A.E., Hiscott, R.N. and Yasar, D., 1999. Oscillating Quaternary water levels of the Marmara Sea and vigorous outflow into the Aegean Sea from the Marmara Sea-Black Sea drainage corridor. Marine Geology, 153(1-4): 275-302.

Arkhangel'skiy, A.D. and Strakhov, N.M., 1938. Geological structure and history of the evolution of the Black Sea. Izv. Akad. Nauk SSSR, 10: 3-104.

Arthur, M.A. and Dean, W.E., 1998. Organic-matter production and preservation and evolution of anoxia in the Holocene Black Sea. Paleoceanography, 13(4): 395-411.

Atanassova, J. (Editor), 1995. Palynological data of three deep water cores from the western part of the Black Sea. Advances in Holocene Paleoecology in Bulgaria. Pensoft, Sofia, 68-93 pp.

Bahr, A., Lamy, F., Arz, H., Kuhlmann, H. and Wefer, G., 2005. Late glacial to Holocene climate and sedimentation history in the NW Black Sea. Marine Geology, 214: 309-322.

Bailey, T.R., McArthur, J.M., Prince, H. and Thirwall, M.F., 2000. Dissolution methods for strontium isotope stratigraphy: Whole rock analysis. Chemical Geology, 167: 313-319.

Ballard, R.D., Coleman, D.F. and Rosenberg, G.D., 2000. Further evidence of abrupt Holocene drowning of the Black Sea shelf. Marine Geology, 170: 253-261.

Bard, E., Hamelin, B., Fairbanks, R.G. and Zindler, A., 1990. Calibration of the 14C timescale over the past 30,000 years using mass spectrometric U-Th ages from Barbados corals. Nature, 345: 405-410.

Berger, A. and Loutre, M.F., 1991. Insolation values for the climate of the last 10 million years. 
Quaternary Science Reviews, 10: 297-317.

Birck, J.-L., 1986. Precision K-Rb-Sr isotopic analysis; applications to Rb-Sr chronology. Chemical Geology, 56(1-2): 73-83.

Blum, J.D. and Erel, Y., 1997. Rb-Sr systematics of a granitic soil chronosequence: The importance of biotite weathering. Geochimica et Cosmochimica Acta, 61(15): 31933204.

Broecker, W. and Peng, T.-H., 1982. Tracers in the Sea. Lamont-Doherty Geological Observatory, Palisades, NY, 690 pp.

Bruyevich, S.V., 1952. Increasingly fresh waters under recent sediments of the Black Sea. Alad. Nauk SSSR Doklady, 84(3): 575-577.

Buchardt, B. and Fritz, P., 1980. Environmental isotopes as environemental and climatological indicators. In: P. Fritz and J.C. Fontes (Editors), Handbook of environmental isotope geochemistry. Elsevier, Amsterdam, pp. 473-504.

Cagatay, M.N. et al., 2000. Late glacial-Holocene palaeoceonography of the Sea of Marmara: timing of connections with the Mediterranean and the Black Seas. Marine Geology, 167: 191-206.

Calvert, S.E. and Pedersen, T.F., 1990. Accumulation and preservation of organic carbon in marine sediments; the roles of anoxia vs. preservation. AAPG Bulletin, 74(5): 623.

Chepalyga, A.L., 1984. Inland sea basins. In: A.A. Velichko (Editor), Late Quaternary Environments of the Soviet Union. University of Minnesota Press, Minneapolis, MN, pp. 229-246.

Clark, P.U. and Mix, A.C., 2002. Ice sheets and sea level of the Last Glacial Maximum. Quaternary Science Reviews, 21: 1-7.

Clauer, N., Chaudhuri, S., Toulkeridis, T. and Blanc, G., 2000. Fluctuations of Caspian Sea level: Beyond climatic variations? Geology, 28(11): 1015-1018.

Cox, J.M. and Faure, G., 1974. Isotope composition of strontium in carbonate phase of two cores from Black Sea. In: E.T. Degens and D.A. Ross (Editors), The Black Sea - Geology, Chemistry and Biology. American Association of Petroleam Geologists, Tulsa, OK, pp. 566-569.

Denton, G.H. et al., 1999. Interhemispheric linkage of paleoclimate during the last glaciation. Geografiska Annaler, 81(A): 107-153.

Deuser, W.G., 1972. Late-Pleistocene and Holocene history of the Black Sea as indicated by stable-isotope studies. Journal of Geophysical Research, 77(6): 1071-1077.

Elliot, M., Labeyrie, L.D., Dokken, T. and Manthé, S., 2001. Coherent patterns of ice-rafted debris deposits in the Nordic regions during the last glacial (10-60 ka). Earth and Planetary Science Letters, 194: 151-163.

Fairbanks, R.G., 1989. A 17,000-year glacio-eustatic sea level record: influence of glacial melting rates on the Younger Dryas event and deep-ocean circulation. Nature, 342(6250): 637-642.

Faure, G., 1986. Principles of Isotope Geochemistry. Wiley, New York, NY, 589 pp.

Fleming, K. et al., 1998. Refining the eustatic sea-level surve since the Last Glacial Maximum using far- and intermediate-field sites. Earth and Planetary Science Letters, 163: 327-342.

Görür, N. et al., 2001. Is the abrupt drowning of the Black Sea shelf at $7150 \mathrm{yr}$ BP a myth? Marine Geology, 176: 65-73.

Grootes, P.M., Stuiver, M., White, J.W.C., Johnsen, S. and Jouzel, J., 1993. Comparison of oxygen isotope records from the GISP2 and GRIP Greenland ice cores. Nature, 366: 552- 
554.

Grosswald, M.G., 1980. Late Weichselian ice sheet of Northern Europe. Quaternary Research, 13: $1-32$.

Grosswald, M.G., 1998. Late-Weichselian ice sheets in Arctic and Pacific Siberia. Quaternary International, 45-46: 3-18.

Grosswald, M.G. and Hughes, T.J., 2002. The Russian component of an Arctic ice sheet during the Last Glacial Maximum. Quaternary Science Reviews, 21: 121-146.

Grousset, F.E., Pujol, C., Labeyrie, L., Auffret, G. and Boelaert, A., 2000. Were the North Atlantic Heinrich events triggered by the behavior of the European ice sheets? Geology, 28(2): 123-126.

Gunnerson, C.G. and Ozturgut, E., 1974. The Bosporus. In: E.T. Degens and D.A. Ross (Editors), The Black Sea: Geology, Chemistry, and Biology. American Association of Petroleam Geologists, Tulsa, OK, pp. 99-114.

Hardie, L.A., Smoot, J.P. and Eugster, H.P., 1978. Saline Lakes and Their Deposits: A Sedimentological Approach. Special Publications of the International Assembly of Sedimentology, pp. 7-41.

Hay, B.J., Arthur, M.A., Dean, W.E., Neff, E.D. and Honjo, S., 1991. Sediment deposition in the Late Holocene abyssal Black Sea with climatic and chronological implications. Deep-Sea Research, 38(Suppl. 2): S1211-S1235.

Hemming, S.R., 2004. Heinrich events: massive late Pleistocene detritus layers of the north Atlantic and their global climate imprint. Reviews of Geophysics, 42: RG1005.

Henderson, G.M., Martel, D.J., O'Nions, R.K. and Shackleton, N.J., 1994. Evolution of seawater Sr-87/Sr-86 over the last 400-ka: the absence of glacial interglacial cycles. Earth and Planetary Science Letters, 128(643-651).

Hinderer, M., 2001. Late Quaternary denudation of the Alps, valley and lake fillings and modern river loads. Geodinamica Acta, 14(4): 231-263.

Hiscott, R.N. et al., 2002. Deltas south of the Bosporus record persistent Black Sea outflow to the Marmara Sea since $\sim 10 \mathrm{ka}$. Marine Geology.

Ingram, B.L. and Sloan, D., 1992. Strontium isotopic composition of estuarine sediments as paleosalinity-paleoclimate indicator. Science, 255: 68-72.

Israelson, C. and Buchardt, B., 1999. Strontium and oxygen isotopic composition of east Greenland rivers and surface waters: implcation for palaeoenvironemtnal interpretation. Palaeogeography Palaeoclimatalogy Palaeoecology, 153: 93-104.

Jones, G.A. and Gagnon, A.R., 1994. Radiocarbon chronology of Black Sea sediments. Deep Sea Research, 41(3): 531-557.

Jones, G.A. and Keigwin, L.D., 1988. Evidence from Fram Strait ( $\left.78^{\circ} \mathrm{N}\right)$ for early deglaciation. Nature, 336: 56-59.

Kalicki, T. and Sanko, A.F., 1998. Palaeohydrological changes in the Upper Dneper Valley, Belarus, during the last 20,000 years. In: G. Benito, V.R. Baker and K.J. Gregory (Editors), Palaeohydrology and Environmental Change. John Wiley \& Sons, Ltd., Chichester, England, pp. 125-135.

Kaplin, P.A. and Selivanov, A.O., 2004. Lateglacial and Holocene sea level changes in semienclosed seas of North Eurasia: examples from the contrasting Black and White Seas. Palaeogeography Palaeoclimatalogy Palaeoecology, 209: 19-36.

Kelts, K. and Hsu, K.J., 1978. Freshwater carbonate sedimentation. In: A. Lerman (Editor), Lakes: Chemistry, Geology, Physics. Springer-Verlag, New York, pp. 295-323. 
Khrischev, K. and Georgiev, V., 1991. Regional washout on the Pleistocene-Holocene boundary in the western Black Sea depression. Comptes rendues de l'Academie bulgare des Sciences, 44(9): 69-72.

Knutz, P.C. et al., 2002. Multidecadal ocean variability and NW European ice sheet surges during the last deglaciation. Geochemistry Geophysics Geosystems, 3(12): doi:10.1029/2002GC000351.

Koc, N. and Jansen, E., 1994. Response of the high-latitude Northern Hemisphere to orbital climate forcing: Evidence from the Nordic Seas. Geology, 22: 523-526.

Krom, M.D., Michard, A., Cliff, R.A. and Strohle, K., 1999. Sources of sediment to the Ionian Sea and western Levantine Basin of the Eastern Mediterranean during S-1 sapropel times. Marine Geology, 160(1-2): 45-61.

Kroonenberg, S.B., Rusakov, G.V. and Svitoch, A.A., 1997. The wandering of the Volga delta: a response to rapid Caspian sea-level change. Sedimentary Geology, 107: 189-209.

Kvasov, D.D., 1968. Paleohydrology of eastern Europe in late Quaternary time, Yezhegodnkkh Chetniyakh Pamyati L.S. Berga Doklady. Izd. Nauka, Leningrad, pp. 65-81.

Lambeck, K. and Bard, E., 2000. Sea-level change along the French Mediterranean coast for the past 30000 years. Earth and Planetary Science Letters, 175: 203-222.

Lane-Serff, G.F., Rohling, E.J., Bryden, H.L. and Charnock, H., 1997. Post-glacial connection of the Black Sea to the Mediterranean and its relation to the timing of sapropel formation. Paleoceanography, 12(2): 169-174.

Lehman, S.J. et al., 1991. Initiation of Fennoscandian ice-sheet retreat during the last deglaciation. Nature, 349: 513-316.

Major, C.O., Ryan, W.B.F., Lericolais, G. and Hajdas, I., 2002. Constraints on Black Sea outflow to the Sea of Marmara during the last glacial-interglacial transition. Marine Geology, 190: 19-34.

Mangerud, J., Astakhov, V., Jakobsson, M. and Svendsen, J.I., 2001. Huge Ice-age lakes in Russia. Journal of Quaternary Science, 16(8): 773-777.

Manheim, F.T. and Chan, K.M., 1974. Interstitial waters of Black Sea sediments: New data and review. In: E.T. Degens and D.A. Ross (Editors), The Black Sea: Geology, Chemistry, and Biology. American Association of Petroleum Geologists, Tulsa, OK, pp. 155-180.

McManus, J.F., Francois, R., Gherardi, J.-M., Keigwin, L.D. and Brown-Leger, S., 2004. Collapse and rapid resumption of Atlantic meridional circulation linked to deglacial climate changes. Nature, 428(22 April 2004): 834-837.

Menabde, I.V. and Svitoch, A.A., 1990. About the character of the connection between the Caspian and Black seas in the Late Pleistocene (in Russian), Caspian Sea: Problems of Geology and Geomorphology. Nauka, Moscow, pp. 34-41.

Mudie, P.J., Rochon, A., Aksu, A.E. and Gillespie, H., 2004. Late glacial, Holocene and modern dinoflagellate cyst assemblages in the Aegean-Marmara-Black Sea corridor. Rview of Palaeobotany and Palynology, 256: 1-26.

Müller, G. and Stoffers, P., 1974. Mineralogy and petrology of Black Sea sediments. In: E.T. Degens and D.A. Ross (Editors), The Black Sea: Geology, Chemistry, and Biology. American Association of Petroleam Geologists, Tulsa, pp. 200-248.

Nevesskaya, L.A., 1965. Late Quaternary bivalve mollusks of the Black Sea: Their systematics and ecology. Akad. Nauk SSSR Paleont. Inst. Trydy, 105: 1-390.

Palmer, M.R. and Edmond, J.M., 1989. The strontium budget of the modern ocean. Earth and Planetary Science Letters, 92: 11-26. 
Popov, G.I., 1973. New data on the stratigraphy of Quaternary marine sediments of the Kerch Strait. Doklady Akademii Nauk SSSR, 213(4): 84-86.

Rosenthal, Y. and Katz, A., 1989. The applicability of trace elements in freshwater shells for paleogeochemical studies. Chemical Geology, 78: 65-76.

Ross, D.A., 1978. Summary of results of Black Sea Drilling. In: E.T. Degens and D.A. Ross (Editors), Initial Reports of the Deep Sea Drilling Project, Volume 42. US Gov't Printing Office, Washington, DC, pp. 1149-1178.

Ross, D.A. and Degens, E.T., 1974. Recent sediments of the Black Sea. In: E.T. Degens and D.A. Ross (Editors), The Black Sea: Geology, Chemistry, and Biology. American Association of Petroleam Geologists, Tulsa, OK, pp. 183-199.

Ross, D.A., Degens, E.T. and MacIlvaine, J., 1970. Black Sea: recent sedimentary history. Science, 170(9 October): 163-165.

Rossignol-Strick, M., 1995. Sea-land correlation of pollen records in the eastern Mediterranean for the glacial-interglacial transition: biostratigraphy vs radiometric time-scale. Quaternary Science Reviews, 14: 893-915.

Rozanski, K., Araguas-Araguas, L. and Gonfiantini, R., 1992. Relation between long-term trends of oxygen-18 isotope composition of precipitation and climate. Science, 258: 981-985.

Ryan, W.B.F., Major, C.O., Lericolais, G. and Goldstein, S.L., 2003. Catastrophic flooding of the Black Sea. Annual Reviews of Earth and Planetary Sciences, 31: 525-554.

Ryan, W.B.F. et al., 1997. An abrupt drowning of the Black Sea shelf. Marine Geology, 138: 119-126.

Schrader, H., J., 1979. Quaternary paleoclimatology of the Black Sea basin. Sedimentary Geology, 23(1 4): 165 -180.

Schrag, D.P., 1999. Rapid analysis of high-precision Sr/Ca ratios in corals and other marine carbonates. Paleoceanography, 14(2): 97-102.

Scourse, J.D., Hall, I.R., McCave, I.N., Young, J.R. and Sugdon, C., 2000. The origin of Heinrich layers: evidence from $\mathrm{H} 2$ for European precursor events. Earth and Planetary Science Letters, 182: 187-195.

Shcherbakov, F.A. and Babak, Y.V., 1979. Stratigraphic subdivision of the Neoeuxinian deposits in the Black Sea. Oceanology, 19(3): 298-300.

Shcherbakov, F.A. et al., 1978. Sedimentation on the Continental Shelf of the Black Sea. Nauka Press, Moscow, 211 pp.

Shimkus, K.M., Mukhina, V.V. and Trimonis, E.S., 1973. On the role of diatoms in Late Quaternary sedimentation in the Black sea. Oceanologia, Akad. Nauk CCCP, 13: 10661071.

Shimkus, K.M. and Trimonis, E.S., 1974. Modern sedimentation in Black Sea. In: E.T. Degens and D.A. Ross (Editors), The Black Sea- Geology, Chemistry and Biology. American Association of Petroleum Geologists, pp. 249-278.

Shopov, V., Chochov, S. and Georgiev, V., 1986. Lithostratigraphy of Upper Quaternary sediments from the northwestern Black Sea shelf between the parallels of the Cape Emine and Danube River mouth. Geologica Balcanica, 16(6): 99-112.

Siani, G. et al., 2000. Radiocarbon reservoir ages in the Mediterranean Sea and Black Sea. Radiocarbon, 42(2): 271-280.

Siddall, M. et al., 2003. Sea-level fluctuations during the last glacial cycle. Nature, 423: 853-858.

Skiba, S.I., Scherbakov, F.A. and Kuprin, P.N., 1975. On Paleogeography of the Kerch-Taman region in late Pleistocene and Holocene. Oceanologia, 15(5): 862-867. 
Sperling, M. et al., 2003. Black Sea impact on the formation of eastern Mediterranean sapropel S1? Evidence from the Marmara Sea. Palaeogeography Palaeoclimatalogy Palaeoecology, 190: 9-21.

Stanley, D.J. and Blanpied, C., 1980. Late Quaternary water exchange between the eastern Mediterranean and the Black Sea. Nature, 285(5766): 537-541.

Stein, M. et al., 1997. Strontium isotopic, chemical, and sedimentological evidence for the evolution of Lake Lisan and the Dead Sea. Geochimica et Cosmochimica Acta, 61(18): 3975-3992.

Stoffers, P. and Muller, G., 1978. Mineralogy and lithofacies of Black Sea sediments, Leg 42B Deep Sea Drilling Project. In: J.L. Usher and P. Supko (Editors), Initial Reports of the Deep Sea Drilling Project, vol. 42, Part 2. Ocean Drilling Program, College Station, TX, pp. 373-411.

Stuiver, M. and Reimer, P.J., 2004. CALIB 4.4.

Stuiver, M. et al., 1998. INTCAL98 radiocarbon age calibration. Radiocarbon, 40: 1041-1083.

Svitoch, A.A., 1999. Caspian Sea level in the Pleistocene: Hierarchy and position in the paleogeographic and chronological records. Oceanology, 39(1): 94-101.

Turekian, K.K. and Armstrong, R.L., 1960. Magnesium, strontium, and barium concentrations and calcite-aragonite ratios of some recent molluscan shells. Journal of Marine Research, 18(3): 133-151.

Ünlüata, Ü., Oguz, T., Latif, M.A. and Özsoy, E., 1990. On the physical oceanography of the Turkish Straits. In: L.J. Pratt (Editor), The Physical Oceanography of Sea Straits. NATO/ASI Series. Kluwer, Deventer, The Netherlands, pp. 25-60.

von Grafenstein, U., Erlenkeuser, H., Brauer, A., Jouzel, J. and Johnsen, S.J., 1999. A MidEuropean decadal isotope-climate record from 15,500 to 5,000 years B.P. Science, 284: 1654-1657.

Wall, D. and Dale, B., 1974. Dinoflagellates in the late Quaternary deep-water sediments of the Black Sea. In: E.T. Degens and D.A. Ross (Editors), The Black Sea - Geology, Chemistry and Biology. Amer. Assoc. Petrol. Geol. Mem., Tulsa, pp. 364-380.

Wefer, G. and Berger, W.H., 1991. Isotope paleontology: growth and composiition of extant calcareous species. Marine Geology, 100: 207-248.

Yaltirak, C. et al., 2002. Late Pleistocene uplift history along the southwestern Marmara Sea determined from raised coastal deposits and global sea-level variations. Marine Geology, 192: 283-305.

Zubakov, V.A., 1988. Climatostratigraphic scheme of the Black Sea Pleistocene and its correlation with the oxygen isotope scale and glacial events. Quaternary Research, 29(1): $1-24$. 


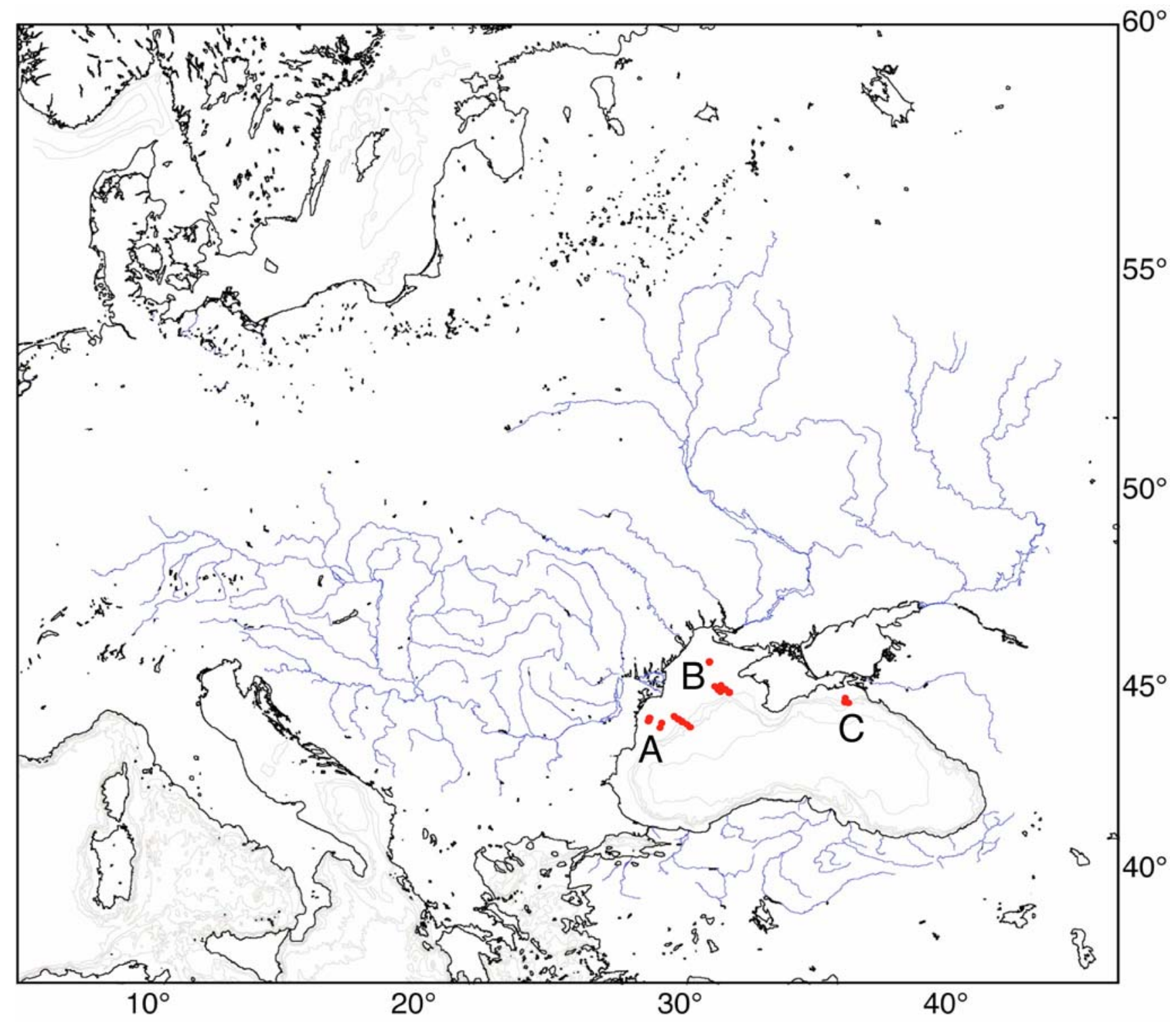

Figure 1 
(A)

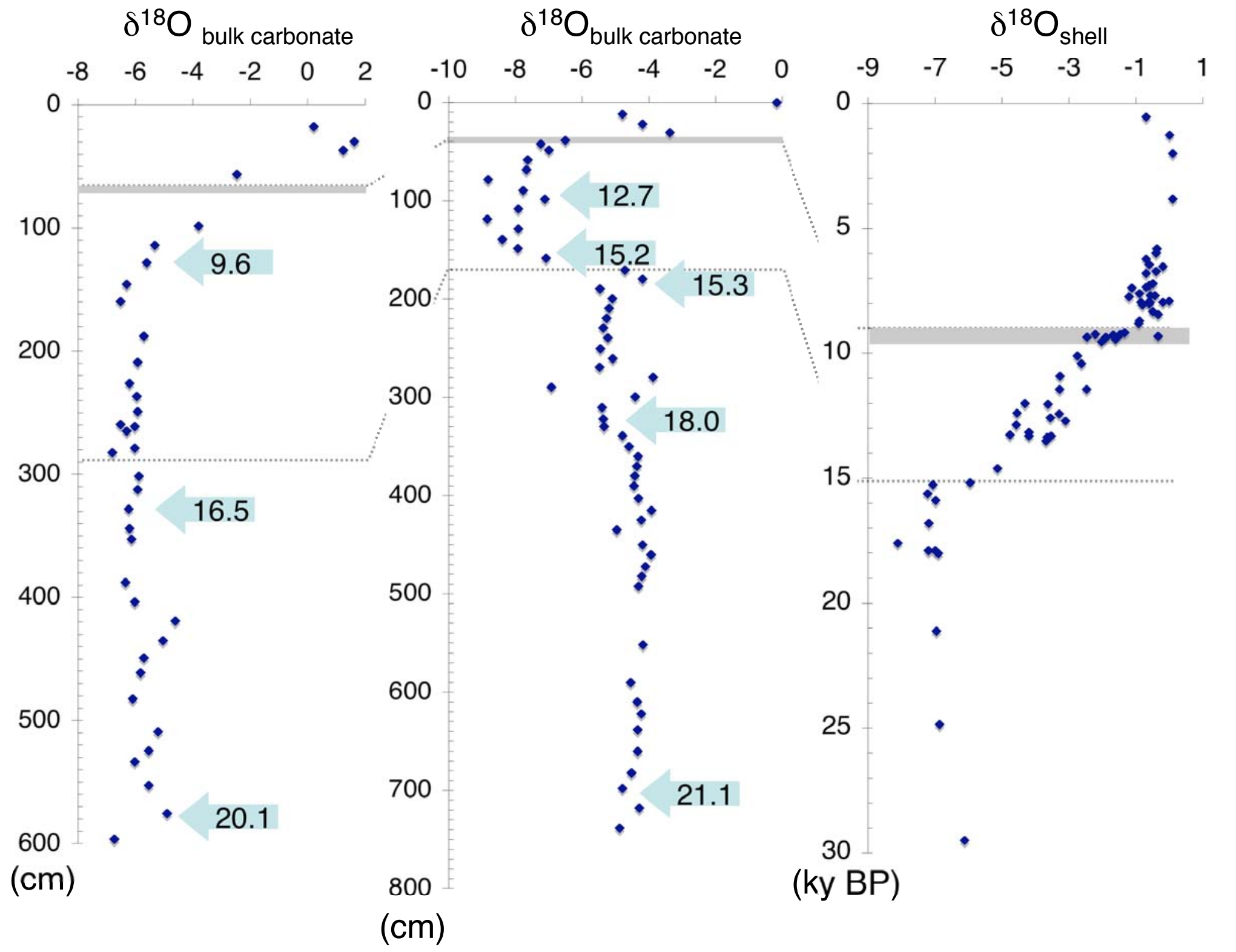




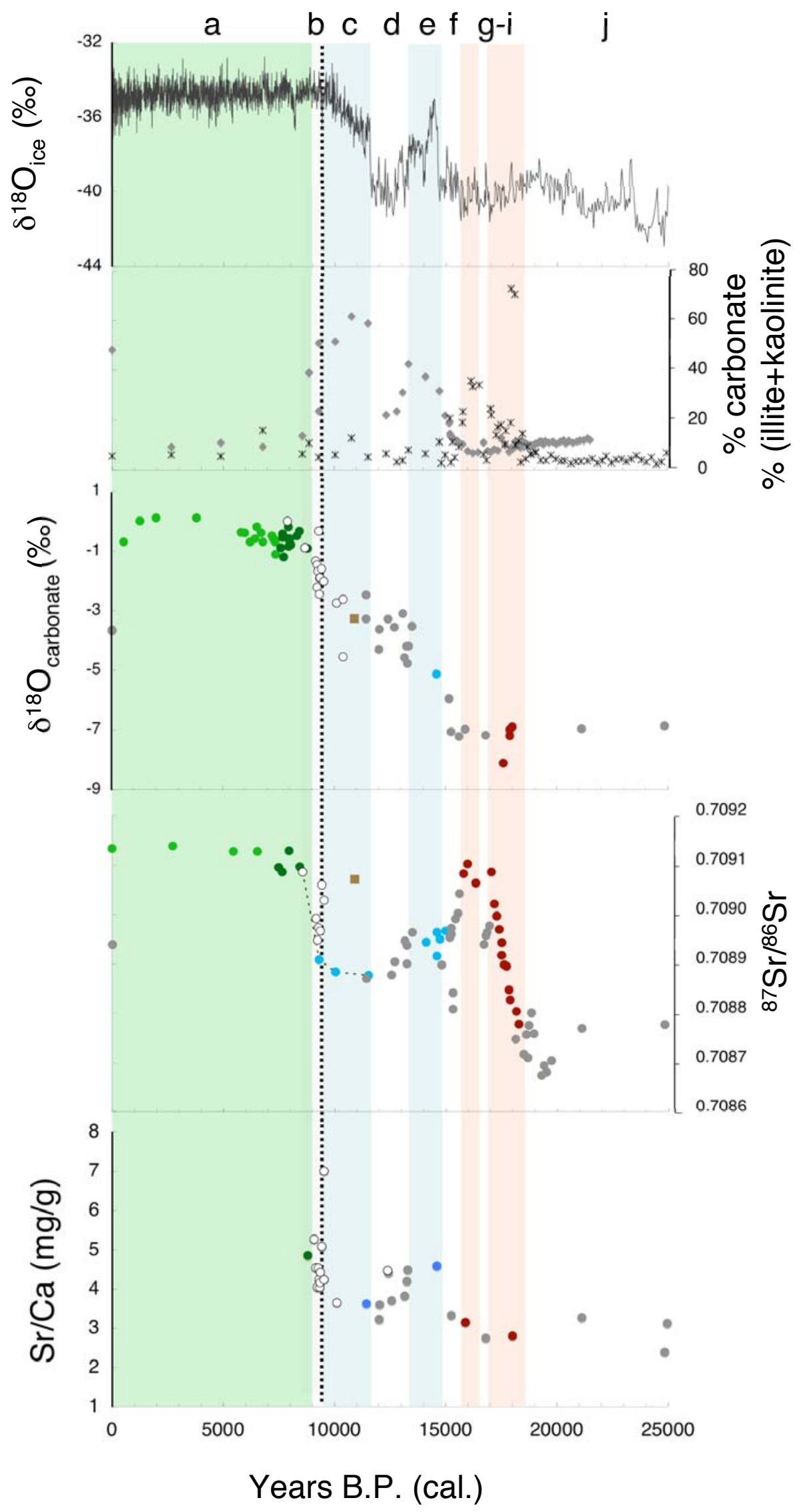

Figure 3 

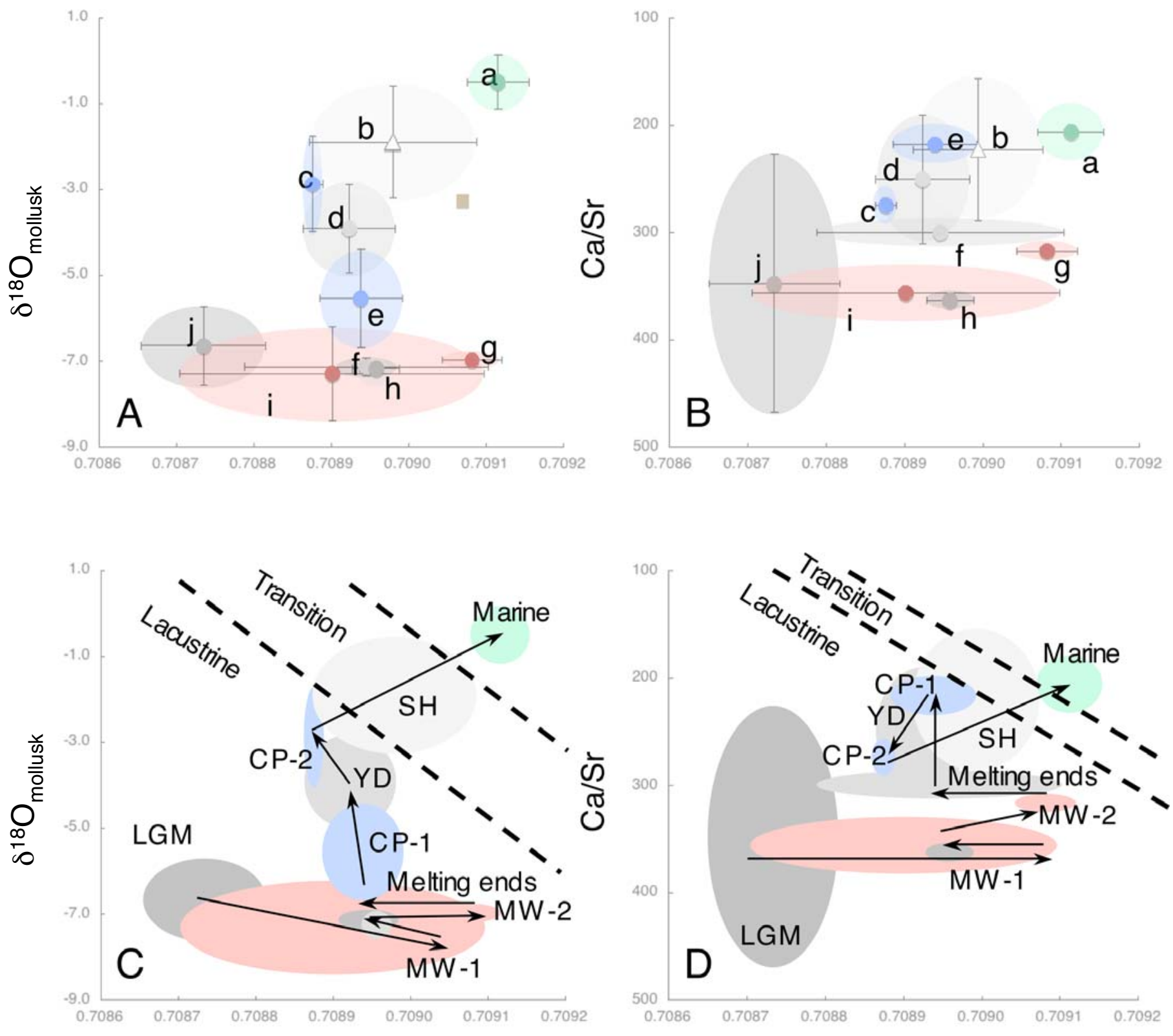

${ }^{87} \mathrm{Sr} /{ }^{86} \mathrm{Sr}$

${ }^{87} \mathrm{Sr} / 86 \mathrm{Sr}$ 


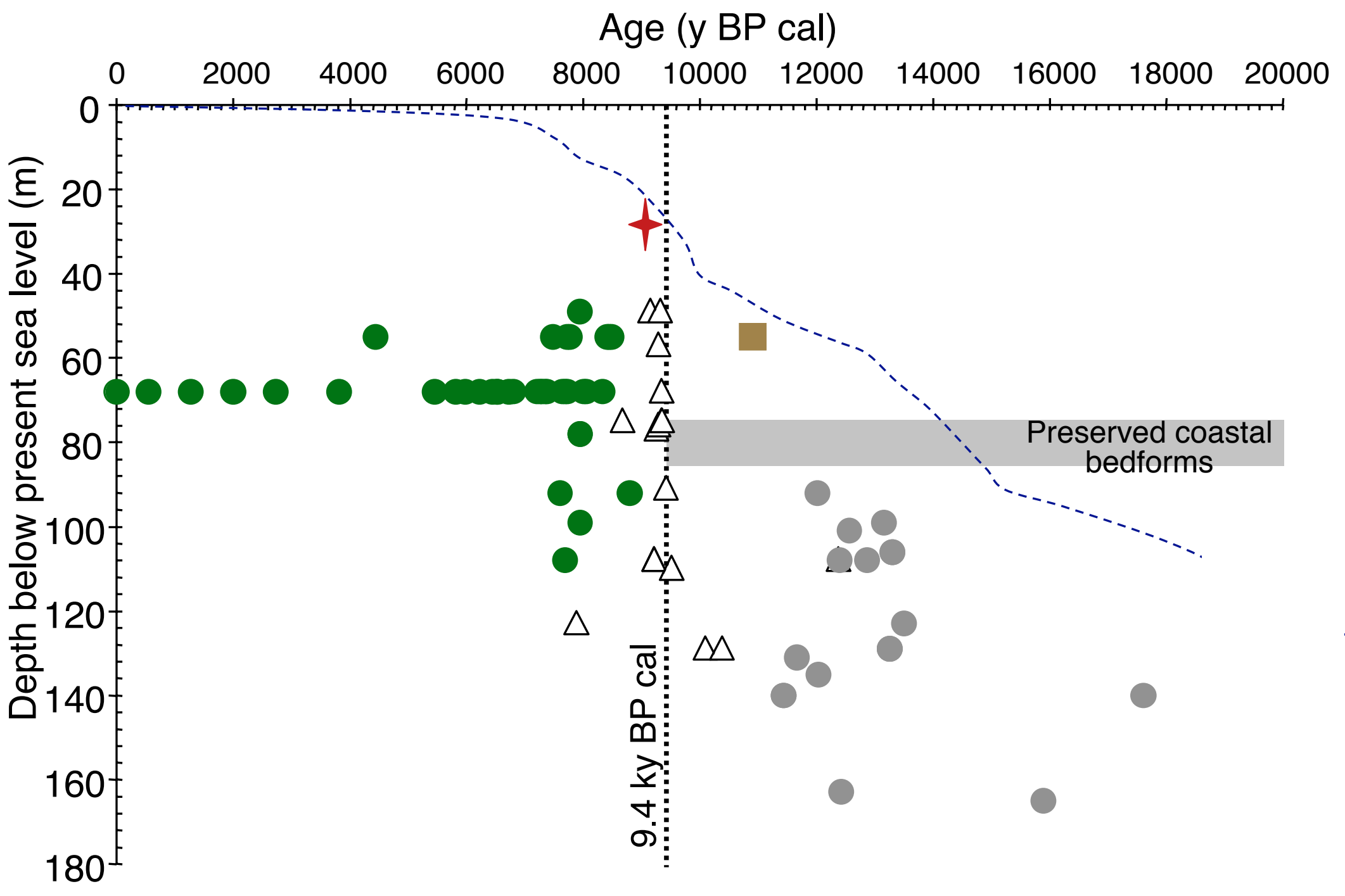

Figure 5 


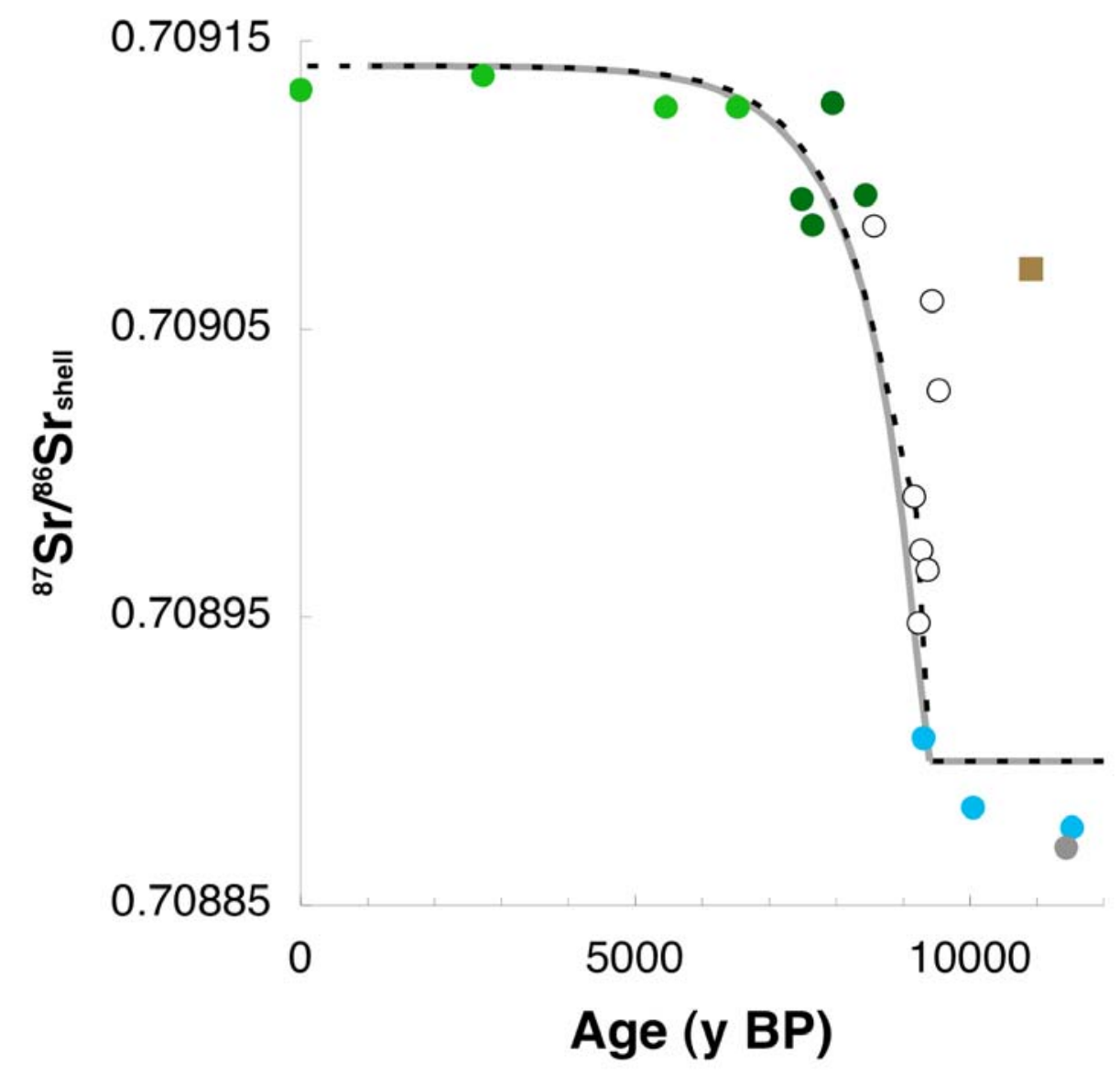

Figure 6 